\title{
From Fray Alonso de la Vera Cruz to Fray Martín de Rada
}

\author{
The School of Salamanca in Asia
}

\author{
Dolors Folch
}

\section{Some Biographical Notes on One of Vitoria's American Disciples: The Intellectual Formation of Alonso de la Vera Cruz at Salamanca}

The members of the School of Salamanca are mainly recognised for their contributions to the development of ius gentium in the wake of the Spanish conquest of the recently discovered Americas. It was then that theologians and jurists of the School were tasked with weighing the excesses of the conquest against the commitment to evangelise the indigenous peoples found there in order to justify this nascent colonial enterprise. Francisco de Vitoria (14831546) is the most renowned of these Salmantine theologians and he proposed his own doctrine on the subject in some of his annual relectiones. ${ }^{1}$ Vitoria spent a number of years studying in Paris. As Thomas Duve reminds us in the opening chapter of this book, Francisco de Vitoria was himself part of a broad intellectual current that had not begun in Salamanca but arrived there with him - which also means that it arrived there later than in Paris -, integrating Salamanca into a broader European and interdisciplinary context. Once in Salamanca, Vitoria obtained the chair in theology in 1526 , having already joined the Dominican Order. His philosophy on how society should be governed and the relationship between peoples was shaped in his courses at Salamanca and condensed in the relectiones he gave between 1529 and 1546, the year of his death. One of his innovations in these annual presentations was to draft the entire text of the relectio in advance, rather than limiting it to the brief outline usually provided for the event, which no doubt greatly facilitated its dissemination either in printed form or in manuscript copies

1 The relectio or repetitio was the formal address that university chairs had to give once a year in a solemn academic ceremony but the majority of them did not fulfill this duty, preferring to pay a fine rather than take the effort to prepare a relectio. 
that circulated among his students. ${ }^{2}$ Some 500 copies of his 1539 Relectio de Indis were produced. ${ }^{3}$

In De Indis and De iure belli, Vitoria dismantled one by one the arguments of the famous Requerimiento, which was written in 1512 by the jurist Juan López de Palacios Rubios who had also studied at the University of Salamanca, and rejected some of the tituli usually alleged to justify Spanish expansion into America. He discarded the right of the pope to make a donation of the recently discovered lands because he only had spiritual but not temporal jurisdiction over those regions, and he rejected the right of the emperor to consider himself the lord of the whole world. He also defended the right of the Natives to live according to their own societal arrangements, even though they were not Christians and wanted to preserve their own culture.

Vitoria was not a radical critic of the conquest but rather of the manner in which it had been carried out, and so he set out eight titles under which he thought it would be legitimate. The first was the obligation to defend free trade and the worldwide movement of men, goods, and ideas. The second advocated the right to preach the Gospel throughout the world. The third defended the necessity of protecting those inhabitants who had already converted to Christianity. The fourth proclaimed that, if the Natives were already Christians, the pope could appoint a Christian king to rule over them. The fifth justified conquest in places where there was tyranny and cruelty, such as human sacrifice. The sixth imagined a scenario in which the Natives freely chose the king of Spain as their sovereign. The seventh authorised conquest if the Spaniards intervened as allies of indigenous peoples in a local war, and the eighth considered a situation in which the inhabitants were incapable of building and administering a res publica. Ultimately, Vitoria was proposing to change the current practice of conquering and ruling over the natives to a protectorate which respected the dominion of the Natives over their own goods and some degree of self-government. ${ }^{4}$ Ius gentium, which laid the foundations for what would become international law, had its origins in the writings of Vitoria and later Hugo Grotius (1583-1645). In both cases, there is a clear connection between ius gentium and European colonial ambitions, as scholars such as Anghie have shown. ${ }^{5}$ Vitoria and Grotius also agreed that the sea was international territory which all nations had the right to navigate without let or hindrance.

2 Pereña, La Escuela de Salamanca, 49-51.

3 Pereña, La Escuela de Salamanca, 55 .

4 Pereña, La Escuela de Salamanca, 49.

5 Anghie, "Francisco de Vitoria and the colonial origins of international law". 
Vitoria enjoyed widespread influence, as can clearly be seen in the writings of Alonso de la Vera Cruz and Martín de Rada, and he was decisive in the drafting of the Leyes Nuevas (1542), which were as welcomed in Spain as they were de facto rejected in America. He also set up a theological and juridical school where his students engaged with his ideas, starting with Domingo de Soto (1496-156o) whose relectiones from 1533 until 1545 would also be widely distributed, ${ }^{6}$ and whose 1553 book, De iustitia et iure, would be published in approximately 25 editions over the next five decades. ${ }^{7}$ But this was not all, Vitoria's ideas reappeared time and again over the next half century in the writings of former students of Salamanca who formed a veritable lobby. On the other hand, as Lidia Lanza and Marco Toste point out in this volume, Salamanca was in turn influenced by other prominent Iberian universities like Coimbra. Salamancan students emerged everywhere as Dominicans, Augustinians, conquistadores, professors, and high functionaries of the Crown. In 1539 and 1541, Emperor Charles v charged Francisco de Vitoria with selecting some of his best students to go to the Indies as missionaries and the archbishop of Mexico, Juan de Zumárraga, unsuccessfully asked the emperor for Domingo de Soto to come. The influence of the former students of Salamanca was widespread inasmuch at least 182 of the professors, missionaries, and high functionaries who went to the Indies between 1534 and 1580 were former students of the University of Salamanca. ${ }^{8}$ The influence of Salamanca in America was also institutional, as discussed in the contribution of Enrique González in this volume, because the universities at Santo Domingo, Lima, and Mexico were established along some of the same constitutional lines as Salamanca.

Fray Alonso de la Vera Cruz (1507-1584) should be considered against this backdrop. Baptised Alonso Gutiérrez Gutiérrez, he was born in 1507 in Caspueñas near Guadalajara into a family of means who paid for him to have an excellent education. In 1524, at age 17 , he entered the University of Alcalá, where he studied grammar, literature, and rhetoric. Alcalá was a first-rate academic institution where Antonio de Nebrija and the Augustinian Tomás de Villanueva had already made names for themselves. Villanueva, who had a premonitory intuition that the New World would be the refuge of the Church to counter the advances of the Turks and Protestants, is attributed with the idea of sending the first four boatloads of Augustinians to America. Tomás de

6 Martín de la Hoz, "Las relecciones teológicas de Domingo de Soto: cronología y ediciones", 438-440.

7 Pereña, La Escuela de Salamanca, 49-57.

8 According to the classical account of Pereña which can be complemented by more recent archival findings, Pereña, La Escuela de Salamanca, 88-91. 
Villanueva was a brilliant orator and made a lasting impression on his students, one of whom proved to be one of the most important figures of the School of Salamanca, Domingo de Soto (1494-156o), whose work would be referenced by both Alonso de la Vera Cruz and Martín de Rada. His idea that missionaries should study in order to optimise their ability to preach the Gospel would have an impact on Vera Cruz, ${ }^{9}$ who added a dedication to Villanueva at the beginning of his Physica Speculatio. ${ }^{10}$

Having completed his initial studies at Alcalá, Alonso Gutiérrez moved on to the University of Salamanca in 1526 . He studied arts and theology there and, according to a frequently quoted passage of Juan de Grijalva's chronicle - which was the first historical account of the establishment of the Augustinian Order in New Spain -, he was "very dear to the most learned Fray Francisco de Vitoria. [...] Father Vitoria gave him the title of Master [...], he came to be highly thought of at that university [...] and read Arts there with great success".11 Gutiérrez remained at Salamanca until 1536 and it was a decade that left an indelible mark on his future path. Even if he was already in Mexico when Vitoria gave the relectiones De Indis and De iure belli (153839), he managed to know the content of both texts. In fact, Vitoria's criticism of the way in which the conquest had been carried out and his proposal of the titles that could justify it profoundly shaped Gutiérrez's understanding of the topic.

According to Grijalva, Gutiérrez was close to obtaining the chair in theology at Salamanca when Fray Francisco de la Cruz, a tireless recruiter of Augustinians for the American missions, came to the city. In 1533, after he had selected 12 other friars, including Fray Juan de Alva, another student from Salamanca who would advocate tirelessly for the native neophytes in both Mexico and in the Philippines, "he searched for a very learned and virtuous man who could read the Arts and Theology to the friars, seeing this as essential and necessary both for the splendour of the religion and for resolving the great difficulties that had arisen in these regions at the time concerning the Sacraments and privileges". ${ }^{12}$

9 Álvarez, "Fray Tomás de Villanueva", 68 and 73.

10 Álvarez, "Fray Tomás de Villanueva", 64-88.

11 Vera Cruz would have been "muy querido del doctísimo fray Francisco de Vitoria. [...] Diole el padre Vitoria el título de Maestro [...], alcanzó grande opinión en aquella Universidad [...] y leyó en ella Artes con grandísima aceptación", Grijalva, Crónica, 327.

12 "Buscó un hombre muy docto y virtuoso, que leyese Artes y Teología a los religiosos: teniendo en cuenta por cosa esencial y necesaria la de las letras, así para el lustre de la religión como para resolver las grandes dificultades que en esta tierra se ofrecían por momentos en materia de Sacramentos y privilegios", Grijalva, Crónica, $5_{8}$. 
Alonso Gutiérrez met these requirements: he was a man of austere habits and inextinguishable vitality "who slept little and studied a lot". ${ }^{13} \mathrm{He}$ professed as an Augustinian upon his arrival at the port of Veracruz and, in honour of the place and the significance of its name, he changed his name to Alonso de la Vera Cruz in keeping with the mission, which was as religious and cultural as it was juridical, that had been entrusted to him, and he would fulfil both aspects of the word. The humanist and scientific education which Vera Cruz had received at Salamanca translated into the development of educational, cultural, and scientific centres in Mexico and into his abundant writings and defence of indigenous peoples.

\section{The First Cultural, Educational, and Scientific Centres in Michoacán}

Vera Cruz established the first libraries in Michoacán, bringing as many books as he could from Spain. He began transporting them from his first voyage, given that he had been explicitly entrusted with training missionaries in the arts and theology. This shipment of books and scientific materials immediately resulted in the creation of libraries to support the Augustinian colleges in Tiripetío, Tacámbaro, and Atotonilco in the region of Michoacán, where Vera Cruz settled after having spent a year as the master of novices in Mexico. According to the second Augustinian chronicler, Diego de Basalenque, "Tiripetío was the first place, at least for the Order of Saint Augustine, where Arts and Theology began to be read publicly and chairs were created", while, in Atotonilco, "he established a very nice library, superior to and better stocked than the one he set up in Tiripetío"14 Vera Cruz used these texts exhaustively to prepare his classes and sermons. Many of these books have survived and can be found today in the Museo Michoacano in Morelia. ${ }^{15}$

He immediately joined the faculty of the University of Mexico when it was established in 1553, holding the chair of Holy Scripture, which later became the chair of Saint Thomas Aquinas, declared equivalent to the prima chair of

13 "De poco dormir y mucho estudio", Basalenque, Historia, 108-9. Basalenque's Historia was published posthumously, he died in 1651 .

14 "Tiripetío fue el primer lugar, por lo menos para la orden de San Agustín, donde se comenzó a leer públicamente y en cátedra, las mayores de Artes y Teología". In Atotonilco "fundó una muy linda librería mejor y más copiosa de la que puso en Tiripetío", Basalenque, Historia, 74 .

Cerezo, Alonso de Veracruz y el derecho de gentes, 11. 
theology -held by the Dominicans- and created specifically for him. He was considered "the most eminent master in Arts and Theology that there is in this land". ${ }^{16}$ It was a university with a very noticeable presence of former students of Salamanca, mainly Dominicans and Augustinians, with whom Vitoria's observation "that [the Natives] should seem so behind and dull is due [...] to their bad and barbarous education" resonated. ${ }^{17}$

Between 1562 and 1573, he spent a long and difficult period in Spain where he had to defend himself from the accusations of bishop Alonso de Montúfar, who was furiously trying to impede the printing of Vera Cruz's writings against the imposition of the tithes on the natives. He also fought fiercely and successfully against a recent revocation of the privileges previously granted to the friars to support their missionary commitments and looked for books that were missing from the Augustinian libraries in New Spain in Salamanca and many other places across Spain. Besides, he brought back a notable variety of materials and scientific instruments for both research and navigation.

He created an outstanding collection in the college [of San Pablo in Mexico City] which he had brought from Spain the year before [1573], having searched, as he himself says, in various places and universities where there were books from all faculties, on all the arts and known languages. The first lot was 60 crates of books which this great man kept adding to whenever anything came to his attentions that was not in the collection. He adorned the library with maps, globes of the sky and earth, astrolabes, clocks, cross-staffs, planispheres, in short, all those instruments that serve the liberal arts [...]. There is no book at San Pablo or Tiripetío that is not written on or annotated by his own hand from the first leaf to the last, and the majority of the San Agustín collection has these notes in all faculties, even though it seems impossible to have browsed so many books, much less to have read them. ${ }^{18}$

16 According to Cervantes de Salazar, who gave the inaugural lecture at the newly established University of Mexico. Lazcano, Fray Alonso de Veracruz, 58.

17 Mojarro, "La defensa del indio en la temprana literatura hispano-filipina colonial", 17.

18 "Puso en el colegio [de San Pablo, en México ciudad] una insigne librería que el año antes [1573] había traído de España, buscada como él mismo dice, de diversas partes y universidades, donde había libros de todas facultades, de todas las artes y lenguas de que se tenía noticia. El primer puesto fue de sesenta cajones de libros, a los cuales fue añadiendo este gran varón todos aquellos que venían a su noticia y no estaban en la librería. Adornó la librería con mapas, globos celestes y terrestres, astrolabios, orologios, ballestillas, planisferios y al fin todos aquellos instrumentos que sirven a las artes liberales [...] Ningún libro hay en San Pablo ni en Tiripetío, que no esté rayado y marginado, de la primera hoja hasta la última, de su letra y la mayor parte de la librería de San Agustín tiene estas notas, en 


\section{The Common Interests of Mexican Augustinians Trained at Salamanca: Vera Cruz and Rada on Astronomy, Cosmography, Architecture, and Buying Books}

Vera Cruz's interest in endowing the New World not only with books but also with scientific instruments was generally shared by the former students of Salamanca, who were already an identifiable community in the New World. Halfway through the 16th century, Salamanca was much more than a humanist centre of juridicalpolitical discussion, it was one of the best universities in the world and one of scientific innovation. Besides, as Duve points out in his introduction to this volume, the School of Salamanca has to be considered not as a group of authors working in a definite place (Salamanca, Castile), but as a specific mode of producing normative knowledge being practiced in different and, sometimes, very distant places, and as a communicative process performed by a multitude of actors.

One of the great developments of the century was the heliocentric theory proposed by Copernicus. Although his magnum opus, De Revolutionibus orbium coelestium, was not published until 1543, Copernicus had been distributing a short work, the Commentariolus, since 1507 in which he laid out his first version of the heliocentric theory. This text soon found its way to Salamanca and it is no coincidence that it was at this university that Diego de Zúñiga $(1536-1598),{ }^{19}$ the Spanish theologian who, at this time, was most acquainted with Copernicus' ideas, would later teach. His impact on the university would be felt after Vera Cruz and Rada had passed through its hallowed halls because it was only in 1561 that the statutes of the University of Salamanca allowed Copernicus's work to be read in class. Although the majority of astrologists remained geocentric in their views, Copernicus's tables were nevertheless used even before 1561, especially in navigation, and were in fact the calculation tables that Vera Cruz and Rada took from Salamanca to Mexico and which Rada and Urdaneta used, in addition to the Alfonsine tables, ${ }^{20}$ to reach the Philippines and to determine their geographical location. ${ }^{21}$ Rada explicitly

todas las facultades, que parece que no fue factible hojear tantos libros, cuanto y más leerlos", Grijalva, Crónica, 327 and 401.

19 Although Diego de Zúñiga took the precaution of hiding his defence of heliocentrism in the depths of his 1584 Comentarios de Job (verse 5 , chapter 9) it did not go unnoticed in the long run and the book was included in the Index of Forbidden Books in 1616.

20 Astronomical tables based on the work of Ptolemy that were further developed by the Arabs and translated into Spanish by the Toledo School of Translators in the 13th century.

21 Urdaneta discarded the Alfonsine tables and navigated "según la quenta de Copérnico, a quien en esta quenta seguiré, como más moderno”, Rodríguez, Historia de la Provincia agustiniana de Filipinas, vol. XIII, 551-552. Rada stated in a letter to Vera Cruz from Manila 
said that he had not only used the Prutenic tables but also carried a book by Copernicus on astronomy with him.

Vera Cruz's scientific interest is evident in his fourth book, the Physica speculatio, published in Mexico in 1557, the year Rada arrived, which is a treatise on the philosophy of nature, subdivided into a series of treatises that exactly followed the Aristotelian template. With the explicit intention of complementing the theme of the last treatise, Vera Cruz included an entire book by another author at the end, the Compendio de la Esfera by the 13th-century author Campanus de Novara. ${ }^{22}$ It was a book on astronomy and in the seventeenth chapter, entitled "That the earth is in the centre of the sky", it set out not the geocentric theory, as the title might suggest, but rather the heliocentric, obviously with the aim of refuting it. ${ }^{23}$ Vera Cruz included this entire book without additional commentary but no one could miss the significance of this text in the explosive atmosphere of the 16th century. Campanus's book was suppressed in the three subsequent Salamanca editions of Physica Speculatio $(1562,1569$, and 1573$)$.

One of the former students of Salamanca transplanted to Mexico was Martín de Rada (1533-1578), who had studied in Paris for a while whilst very young and then completed his studies at Salamanca between 1553 and $1556 .{ }^{24}$ It was not a casual choice: in fact, as we have already mentioned with regard to Vera Cruz, both universities were strongly related at this time. Vitoria had already died but his influence on Rada is explicit as is that of Domingo de Soto, who currently held his position, because Rada referenced them both. ${ }^{25}$ In 1557 Rada, who had become an Augustinian, left for Mexico where he coincided with Vera Cruz for six years. Rada arrived preceded by his great prestige, Grijalva said of him "Martín de Rada came, a man of rare ingenuity, a good theologian, and most eminent in mathematics and astronomy, which seemed to be a monstrous thing", ${ }^{26}$ which is corroborated by other contemporary sources

that he had taken "las tablas alfonsinas y pruténicas (Copernican)" to the Philippines. Rada, "Carta a fray Alonso de la Vera Cruz, Manila, 3 de junio de 1576", Bibliothèque Nationale de France (BNF), Fonds Espagnol, M F 13184, 325.7, fols. 35-36.

22 As the Physica Speculatio says explicitly on the cover of its Mexican edition, "Accessit compendium spherae Campani ad complementum tractatus de coelo".

23 Navarro, "La Physica Speculatio de fray Alonso de la Veracruz", 59.

24 Folch, "Biografia de Martín de Rada".

25 Rada, "Carta a fray Alonso de la Vera Cruz, Calompit, 16 de julio de 1577", BNF, Fonds Espagnol, M F 13184, 325.8, fols. 37-38.

26 "Vino Martín de Rada, hombre de raro ingenio, buen teólogo y eminentísimo en matemáticas y astronomía, que parecía cosa monstruosa", Grijalva, Crónica, 205. 
like the Augustinian José Sicardo who emphasised that Rada came from Salamanca. ${ }^{27}$

Rada was in Mexico when the need to find a route to Asia across the Pacific was again raised. In 1564, he embarked with Urdaneta on the Legazpi expedition to the Philippines. As a former student of Salamanca and a disciple of Vera Cruz, Rada set out for the Philippines with a stash of books that reproduced the curriculum of Salamanca to the letter. This was also the curriculum of the University of Mexico which was established in 1553 in the image of Salamanca, not only in its curriculum, but also in its very administrative and financial organisation. ${ }^{28}$

Euclid and Archimedes on geometry, Ptolemy and Copernicus on astronomy, ${ }^{29}$ Vitellio on perspective, ${ }^{30}$ and Haly Abenragel on judicial [astrology]. ${ }^{31}$ I also have the book on triangles, and the instructions of Monte Regio, ${ }^{32}$ and Cipriano Leovitio's Ephemerides, ${ }^{33}$ and the Alfonsine and Prutenic tables. ${ }^{34}$

27 "Vino Fray Martin de Rada, natural de Pamplona, hijo del convento de Salamanca, grande matemático y astrólogo y theólogo, que después pasó a Filipinas" in Galende, Martin de Rada, 38 and n. 7 .

28 "El emperador dictaminó que todos los doctores gozasen de todas preeminencias de que gozan los doctores de la universidad de Salamanca, proveyendo de sus reales rentas estipendios y salarios públicos para los catedráticos", Grijalva, Crónica, 179.

29 Although Ptolemy's most famous book may have been his Geographia, Rada mentioned him in the field of astronomy and could, therefore, be referring to one of his two other books: Almagest, a treatise on astronomy which allowed the measurement of the celestial bodies -Rada had the prestige of being known as a great astronomer - or the Tetrabiblos, an astrological treatise focusing on the influence of the movements of the planets and stars on human life. Judicial astrology was in fact one of Rada's great interests.

30 The 13th-century Polish physicist whose work on the refraction of light was printed in 1533 .

31 The 11th-century Arab astrologer whose work, which had been translated into Castilian by the School of Translators at Toledo in the 13th century, achieved great fame when it was translated into Latin and printed in Venice in 1485 .

32 Johan Müller (1436-1476), the German astronomer and mathematician known as Regiomontanus, a translation of the name of his native city Königsberg.

33 Cyprian von Leowitz was an astronomer from Bohemia who became famous for his book on eclipses, the Ephemerides, which was published in 1556, that interpreted the movements of the celestial bodies and was used by other scientists, but Regiomontanus's work was more frequently consulted.

34 The Alfonsine tables were astronomical tables based on the work of Ptolemy which were further developed by the Arabs and then translated into Spanish by the Toledo School of Translators in the 13th century. The Prutenic tables were tables with Copernicus's calculations. "De geometria a Euclides y Archymedes, de astronomia a Ptolomeo y Copernico, de perspectiva Vitellio, de judiciaria Hali aben Ragel. Tengo tambien el Libro de triangulis 
Rada also shared Vera Cruz's interest in scientific instruments, and he was especially adept at making them, a point on which all the sources agree. His technical abilities became something of a double-edged sword for the intellectual and missionary as they made him a basic requisite for explorations and conquest (figure 5.1). He died in 1578 returning from a failed expedition to Borneo, where Governor Sande had taken him in order to determine its position. The king himself sought his help in determining the geographical coordinates of his extensive empire, something which, some months before his death at the sea, Rada would comment on to Vera Cruz with ill-concealed irritation and an evident disdain for the armchair geographer Gesio.

Other papers and books and many astronomical tables invented by me have been lost at sea or were burned when Limahon burned down the house in Manila. The prolixity of redoing them all daunts me [...]. I also have to deal with quite a large number of observations that His Majesty sent me, ordering me to do it at the request of a Juan Bautista Gesio, whom I do not know. And it busies me even more because I do not have the instruments to do it and so will have to make them first. ${ }^{35}$

The influence of Salamanca and of Vera Cruz was also decisive in the massive purchase of books that Rada made in China in 1575 where he was a member of a diplomatic expedition which was composed of secular and religious Spaniards. These books have been lost but the list of what he bought was recorded by Loarca, a soldier and encomendero who accompanied him on the expedition. ${ }^{36}$ Rada bought some hundred books, including seven on geography that were

y las direcciones de Monte Regio, y el Ephemerides de Cipriano Leovitio, y las tablas alphonsinas y prutenicas", Rada, "Carta a fray Alonso de la Vera Cruz, Manila, 3 de junio de 1576”, BNF, Fonds Espagnol, M F 13184, 325.7, fols. 35-36. This reading list, suitable for any renaissance 'scientist', is identical on many points to those which made up the essential corpus of the Academia Real Mathematica, founded by Juan de Herrera in the palace in 1584 with the express intention of remedying the deficient teaching of mathematics in Spanish universities at the end of the 16th century. Esteban Piñeiro, "Las academias técnicas en la España del siglo XVI", 11 .

"Otros papeles y libros y tablas muchas astronomicas por mi inventadas se me han perdido en la mar y quemado quando Limahon quemó la casa de Manila. La prolixidad de tornarlas a hazer me espanta. [...]. Tambien me ha de ocupar harto gran summa de observationes que Su Magestad me envia a mandar que haga a petición de un Juan Bautista Gesio, que yo no conozco. Y ocuparme ha mas por la falta que tengo de instrumentos para hazerlas, que havre primero de hazerlos", Rada, "Carta a fray Alonso de la Vera Cruz, Calompit, 16 de julio de 1577”, BNF, Fonds Espagnol, M F 13184, 325.8, fols. 37-38. 


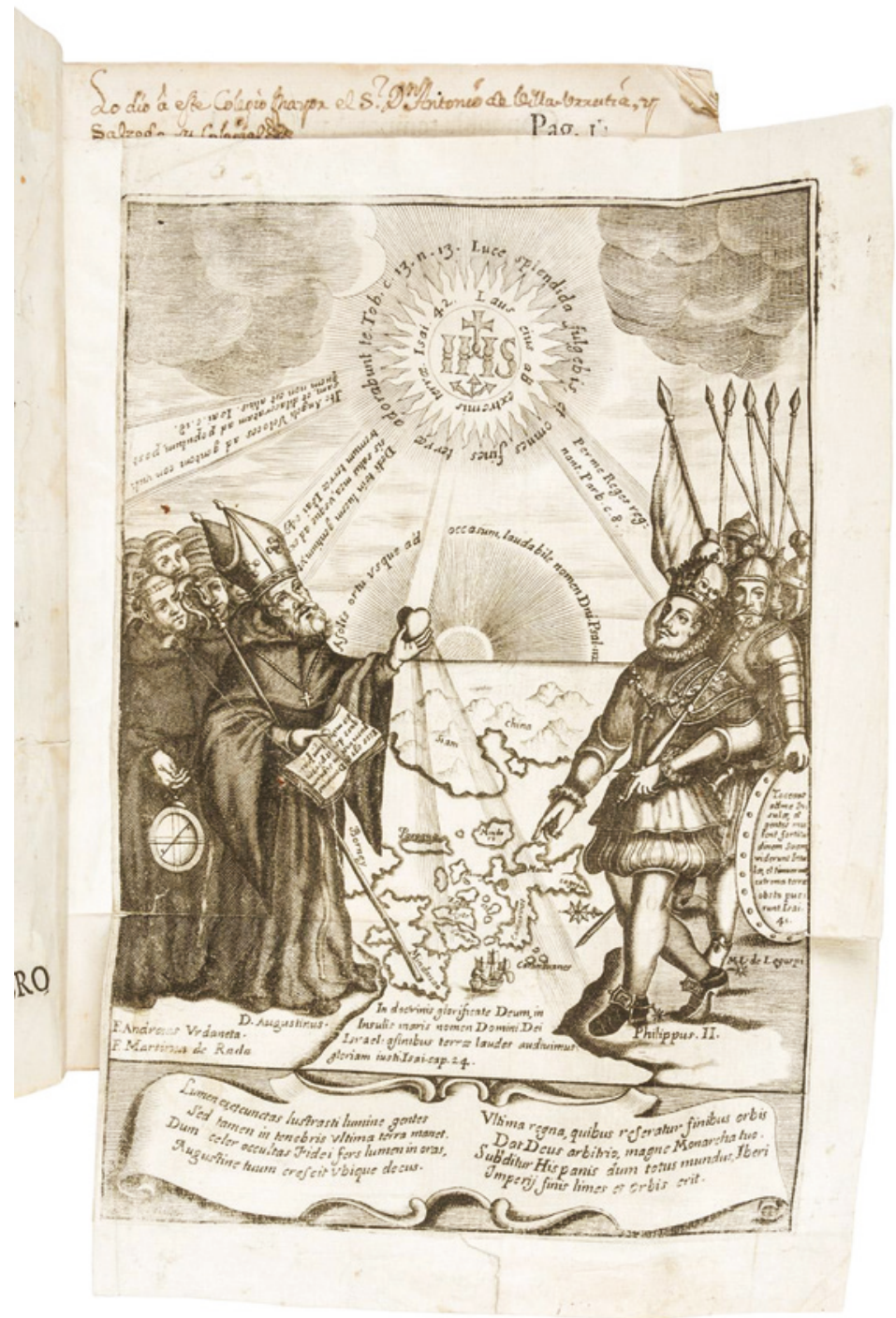

FIGURE 5.1 Martín de Rada holding an astrolabe followed by Andrés de Urdaneta and a troupe of tonsured Augustinian friars. The group of friars responsible for the spiritual conquest of the Philippines - which appear together with China, Borneo, and Siam in the rather chaotic map at the centre of the engraving is presided over by Saint Augustin. In front of the friars are Philip II and Miguel López de Legazpi, leading the military conquerors of the Philippine archipelago, in Gaspar de San Agustín, o.s.A., Conquistas de las islas Philipinas: la temporal por las armas del Señor Don Phelipe Segundo El Prudente; y la espiritual, por los religiosos del Orden de San Agustín, Madrid, 1698: Manuel Ruiz de Murga (Biblioteca AEcID, Madrid, 3 V-381), [s.p.] 


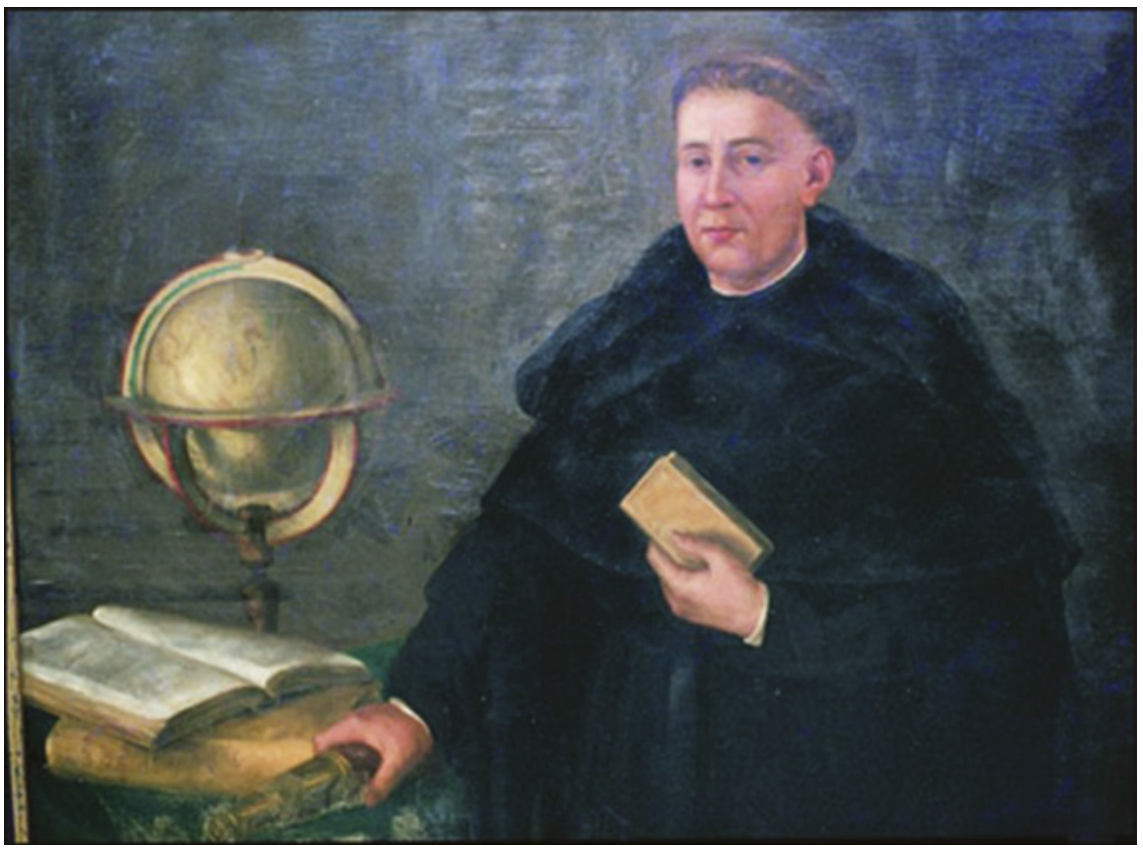

FIgURE 5.2 Víctor Villán, Portrait of Martín de Rada, the missionary-geographer, with a small breviary, geography books, a world globe and a spyglass, 1879 (Museo Oriental de Valladolid)

rich in statistics and maps, which he used in drafting his Relación del viaje a China ${ }^{37}$ becoming the first European to use Chinese books to write about that country.

Vera Cruz and Rada were also leading promoters of architecture. In the 16 th century the Augustinians built the most sumptuous monasteries of New Spain and Vera Cruz promoted the construction of churches and monasteries of grand dimensions with the intention of impressing the Natives with the power of the Church and attracting them to the various celebrations carried out in them. Accounts poured in from the colonies to the Crown that were full of claims, complaints, and protests about the waste and excessive opulence of the Augustinian monasteries, and to these voices was added that of Archbishop Montúfar, who was already involved in a toxic dispute with Vera Cruz over the question of tithes.

37 Folch, “Biografía de Martín de Rada”, 9-18. 
In a monastery of the Augustinian fathers, we have learned that an altarpiece is being made that will cost over 6000 pesos for a hillock where there will never be more than two friars, and the monastery is run most sumptuously, and we have reprimanded [them] to no avail. ${ }^{38}$

The best description of Vera Cruz's architectural activity is found in Basalenque, in his pages are paraded the solid churches, illustrious facades of columns, towers with bells and Castilian clocks, vaulted ceilings and ogives, full coffering, choir stalls and sacristies, altarpieces, paintings, lamps lit at all hours, cloisters and bedrooms with stone floors, monstrances, crosses, and silver chalices, and a lot of silver gleaming in the semi-darkness. There is no doubt that Basalenque was deeply impressed by all he had seen and at times his book reads like an ecclesiastical estate-agent's brochure. ${ }^{39}$

For Rada in the Philippines, the impossibility of emulating the magnificent religious buildings of Spain and America would become a torture. Although he never broached the subject with Vera Cruz, he did so on various occasions with the viceroy of New Spain. "Very little attention is paid to divine worship, even for decent huts in which Mass might be said with great difficulty". ${ }^{0}$ "Do not think that we build as in New Spain", wrote an exasperated Rada. ${ }^{41}$

38 "En un monasterio de los padres agustinos hemos sabido que se hace un retablo que costará más de seis mil pesos para un monte donde nunca habrá más de dos frailes, y el monasterio va superbísimo y hémoslo reñido y no ha aprovechado nada", "Relación de Alonso de Montúfar, Arzobispo de México, 1556", in Palomero Páramo, "El convento agustino en Nueva España: concepto de grandeza", 583 .

39 The Augustinians, as with the other orders, coerced and used the Natives as unpaid labourers to build their monasteries. The volume of Augustinian construction ultimately provided opportunities for Christian Natives. For example, in the construction of the Church of San Agustín in Mexico, the two master builders came from Spain, but the next two levels down, overseers and foremen, were recruited from among literate Natives who knew how to count. Palomero Páramo, "El convento agustino en Nueva España: concepto de grandeza", 593 .

40 "Hazese muy poco caso del culto divino que aun jacales decentes en que se diga misa con gran dificultad se an podido hazer". Rada, "Carta de Fray Martin de Rada al Virrey de la nueva España, Manila, 1 de junio de 1573”, Archivo General de Indias (AGI), Patronato, 24, R.22. This same statement reappeared in its entirety in the memoria that the friars sent that same year with Diego de Herrera to the king, "Memoria de los Religiosos de las yslas del poniente, Manila, [1572]", AG I, Filipinas, 84 .

41 "No se piense que edificamos como en esa nueva españa", "Carta de Rada al virrey de la nueva España, Manila, 10 de agosto de 1572", AGI, Patronato, 24, n. 1, R. 22. 


\author{
The Writings of Alonso de la Vera Cruz and Martín de \\ Rada: Juridical-Political Relectiones and Pareceres, Letters to \\ Authorities, Travel Accounts, Logic, Natural Philosophy
}

As a good student of Salamanca, Vera Cruz was a prolific writer. His four great works covered a wide variety of topics: the first two, Recognitio summularum and Dialectica resolutio ${ }^{42}$ were philosophical in content, the third, Speculum coniugiorum, ${ }^{43}$ concentrated on how to assess and deal with the marital customs of the Natives (especially in Michoacán), ${ }^{44}$ and the last one, Physica speculatio, ${ }^{45}$ gave a cosmovision of the world and universe. Various of his relectiones, although unpublished, had a great impact and were widely disseminated in Mexico in the form of manuscript copies made by his students. The two most important were De dominio infidelium (1554), which addressed the question of the encomiendas, and De iusto bello contra Indos (1556), which analysed both the injustices committed against the Natives and the just titles rationalising the Spanish conquest of America. He followed Vitoria very closely in the latter text, but included his own American experiences as well. ${ }^{46}$ As Virginia Aspe underlines in her contribution to the book, when comparing Vera Cruz's Relectio de dominio infidelum et iusto bello with Vitoria's Relectio de Indis, it becomes clear that Vera Cruz was not a passive recipient of ideas emerging from the alma mater: rather than transplanting them, he culturally translated some of these ideas to the Mexican context, always drawing heavily on the experience he himself had gained in New Spain.

Another relectio, De decimis (1554-55), which examined the idea of collecting tithes from the Natives, aroused the boundless animosity of the archbishop of Mexico, Alonso de Montúfar, in a bitter dispute that would last 20 years and

42 Recognitio summularum, México: Juan Pablo Bricense, 1554; reprinted in Salamanca $(1562,1569,1573,1593)$. Dialectica resolutio, México: Juan Pablo Bricense, 1554; reprinted in Salamanca $(1559,1562,1572)$.

43 México: Juan Pablo Bricense, 1556. Reprinted in Salamanca, 1562. After the Council of Trent, Vera Cruz added an appendix, which was first published in Madrid (Appendix ad Speculum congiugiorum [...]. Iuxta diffinita in sacro universali Concilio Tridentino, circa matrimonia clandestina, Alcalá: Pedro Cosin, 1571), and later added to the two subsequent editions of the Speculum (Alcalá, 1572 and Milano, 1599).

44 See Egío's chapter in this book.

45 Physica speculatio, México: Juan Pablo Bricense, 1556; re-edited in Salamanca (1562, 1569, and 1573) without Campanus's Compendium spherae from the original Mexican edition. Burrus, Vera Cruz's writings, vol. I, 334-335.

46 Both merged into one in a new De dominio infidelium et justo bello put together between 1553 and 1560, which, after being lost for 400 years, was finally published in Burrus, Vera Cruz's writings, vol. II, 83-88. 
which would lead to an episcopal veto on the publication of the text of De decimis in Mexico. ${ }^{47}$ The question centred on the privileges and exemptions enjoyed by the mendicant orders from their arrival in Mexico until the Council of Trent granted the bishops, that is to say to the secular church, responsibility for missionary and diocesan life at the expense of the privileges of the regular clergy. The quarrel was not only religious and administrative, it derived from serious economic issues. The arrival of the secular church made it necessary to collect more funds to cover the cost of its operations and so the mendicant orders railed against the imposition of the tithe on the already hard-pressed natives on the grounds that it would worsen their situation and alienate them from the Church. Vera Cruz became a great defender of the privileges of the regular clergy, opposing the tithe and calling for a restraint on the secular clergy's meddling in the American missions. From the end of the 155os, Montúfar intensified the canonical dispute by turning it into a legal one and denouncing Vera Cruz to the Inquisition on various occasions and impeding the publication of all his works.

The Inquisitor General has taken much care in gathering up all the prohibited books and has fulminated his censures against them. [...] And there is such a quantity of books collected that there are two rooms full [...] I moreover request and beg of Your Highness that no book coming from the City of Mexico made by the hand of Fray Alonso de Vera Cruz should be printed in these parts. ${ }^{48}$

In 1562 Philip II ordered Vera Cruz's presence in Spain, where his manuscript had already arrived and been read and recommended by masters of the standing of Fray Luis de León. ${ }^{49}$ The result of Vera Cruz's journey to Spain, where he

47 There are two bilingual contemporary editions of De decimis, Burrus, Vera Cruz's writings, vol. IV, 113-649 and Barp Fontana, Relectio de decimis, 1554-1555. Tratado acerca de los diezmos.

48 "El Inquisidor general ha tenido mucho cuidado de recoger todos los libros prohibidos y ha fulminado sobre ellos sus censuras.[...] Y hay tanta cantidad de libros recogidos que hay dos cámaras llenas [...] Otrosí pido y suplico a Vuestra Alteza que ningún libro que venga de la ciudad de México hecho por mano de fray Alonso de la Vera Cruz, no se imprima en estas partes [...]", Montúfar, Alarcón, "Denuncia de Gonzalo de Alarcón, en nombre del arzobispo de México”, in Burrus, Vera Cruz's writings, vol. v, 255.

49 Fray Luis de León read De decimis in Salamanca, 25 November, 1561, Lazcano, Fray Alonso de Veracruz (1507-1584), 74. It must be added that the respect between them was mutual as Vera Cruz demonstrated upon learning of the imprisonment of Fray Luis de León by the Inquisition, "Pues a la buena verdad que me pueden quemar a mi si a él lo queman, porque de la manera que él lo dice lo siento yo", Grijalva, Crónica, 400. 
would remain from 1562 to 1573, could not have turned out worse for Montúfar, "he managed, by means of a petition from the king, to get the pope to give him everything he asked for so that the religious could freely administer the Holy Sacraments to the Indians, as had been done before the council". 50

Vera Cruz returned to Mexico not only with the papal bull which restored the mendicant orders' freedom of movement, but also with 6o crates of books, some 12,000 in total, ${ }^{51}$ for which "a section of the hold for up to 12 tons" had been reserved on the ship "so that he could bring the books" thanks to a cédula from Philip II. ${ }^{52}$ Vera Cruz's bibliographic stash, which would end up in the library of San Pablo in Mexico, was very important. It contained not only books on all kinds of subject matters published at various universities, as already confirmed by his biographer Grijalva, but he had also commissioned liturgical books from the Plantin Press in Antwerp, one of the most renowned and prestigious presses.

The conflict between Vera Cruz and Montúfar also extended to the Philippines a few years after the death of Rada with the arrival of the first bishop in Manila (1581), the Dominican fray Domingo de Salazar, another alumnus of Salamanca, who, as Osvaldo Moutin reminds us in his chapter, also attended the courses of Vitoria and Soto in the 1530s. Letters from the Augustinians in the Philippines alerted Vera Cruz to Salazar's intention to limit the privileges of the friars, leading to a harsh correspondence between them, "my contentment was disturbed with what Y.L. writes about what is happening with the religious [...] the dignity seems to have altered you from whom we knew without a mitre". 53

Like many missionaries of the 16th century, Vera Cruz also wrote a great number of letters, ${ }^{54}$ some directed to Philip II and others to Juan de Ovando, the president of the Council of the Indies and another former student of Salamanca, and others directly to the council itself. None of the letters he wrote to Rada survive, although Rada's responses demonstrate that they existed.

$5^{\circ} \quad$ "Consiguió que, a petición del Rey, el Papa diese todo lo que él pedía, para que libremente los religiosos administrasen los santos sacramentos a los indios, según y cómo se hacía antes del Concilio", Grijalva, Crónica, 307.

$51 \quad$ Lazcano, Fray Alonso de Veracruz (1507-1584), 93, n. 231.

52 "Un apartamiento de hasta doze toneladas donde pudiese llevar los dichos libros", Philip II, "Cédula de 23 de febrero de 1572", in Burrus, Vera Cruz's writings, vol. v, 282-283.

53 "El contento se me aguó con lo que V.S. escribe de lo que con los religiosos pasa [...] parece la dignidad averle mudado de lo que sin mitra conocimos", Vera Cruz, "Respuesta al obispo de Manila", in Burrus, Vera Cruz's writings, vol. v, 63-65.

54 A collection of them was published by Burrus, Vera Cruz's writings, vol. III, Spanish writings: I. Sermons, Counsels, Letters, and Reports and vol. v, Spanish writings: II. Letters and reports. 
11 of Rada's letters to figures of authority have been preserved. ${ }^{55}$ Five of them were sent to the viceroy of New Spain, one to the king, one to a relative, Juan Cruzat, an Augustinian in Mexico who was also a friend of Vera Cruz, and five to Vera Cruz, the first of which was written in Manila in 1576 when he had returned from his journey to China and the last was written in Borneo, where he had gone on the disastrous expedition organised by Governor Sande and on which he would meet his death during the return voyage. Rada also actively participated in jointly authored letters sent from Manila, the Memoria de los religiosos of 1572, which is attributed to him, and a co-authored missive to the viceroy from 1577. Two further texts describing the situation in the Philippines also survive, one focusing on the confessions of the encomenderos, which is directed to them, ${ }^{56}$ and the other, a more severe Parecer, ${ }^{57}$ examining the government of the Philippines which was written at the request of the interim governor, Guido de Lavezaris.

His most famous text, the only one that has been preserved apart from his letters, is the Relación del viaje a China, a work of 15 folios which is divided into 20 chapters and which was obviously meant for publication. ${ }^{58}$ Rada sent a copy of the Relación to Vera Cruz as he said in the first extant letter of their correspondence, "After having written to Y.f. and having sent with the letters an account of the journey we made to China last year". ${ }^{99}$ It is unknown whether Vera Cruz made any attempt to publish it but, in any case, it never was.

Encouraged by the requests and the example of Vera Cruz, Rada also attempted to write some books as is clear from the same letter, which was written in response to a now lost letter from Vera Cruz.

55 See bibliography.

56 "Aviso de fray martín de rada sobre las confessiones de los encomenderos, Manila, 1575", Archivo de la Orden de Predicadores, Universidad de Santo Tomás (aOpust), T. VII, fol. 388 .

57 "Parescer del provincial fray martin de rrada agustino sobre las cosas destas yslas, Manila, 21 de junio de 1574", AGI, Patronato 24, R. 29.

58 "Relaçion Verdadera de las cosas del Reyno de Taibin por otro nombre china, 1575", BNF, Fonds Espagnol, MF 13184, 325.9, fols. 15-30.

59 "Despues de aver escripto a V. p. y embiado, con las cartas, la relación del viaje que hizimos el año passado a la China". Rada mentions having made this shipment in his letter of 3 June 1576 to Vera Cruz. Rada, "Carta a fray Alonso de la Vera Cruz, Manila, 3 de junio de 1576 ”, BNF, Fonds Espagnol, M F 13184, 325.7, fols. 35-36. None of Rada's previous letters to Vera Cruz have been preserved and so part of Rada's correspondence has been lost. From the text, it can be deduced that Vera Cruz had direct access to one of the copies of Rada's Relación. 
Y.f. wrote to me to ask whether I had any completed works. Some that I did are now lost. I wrote a book, De recta hydrographie ratione, and a large part of De geometria practica in Castilian as it seemed that none of this material has come out in Castilian, which is incredible, and it is in seven separate books, and then I thought of writing another seven on cosmography and astronomy. And in these past few years, I wrote about judicial astrology, which I still have the first draft of. I have not overburdened myself with it too much as it does not seem to me to be a decent thing for a friar, although we could defend it to those who challenge it undeservedly. I also wrote a book on all the ways of making clocks. Out of all these, if something seems to Y.f. to be proper to be occupied with I shall try to work but I have lost the desire to see my works lost to the seas. ${ }^{60}$

Rada's text oozes with the bitterness of someone far away who lacked contacts and resources. His interests steered him, without a doubt, toward scientific texts such as those he mentioned, like hydrography, geometry, cosmography and astronomy, and some were conceived of as great works in various volumes. The reference to judicial astrology is more bitter still. This was Rada's great love, but the Augustinians were very hesitant to endorse it. Grijalva tore it to pieces with the stroke of a pen, "as regarding judicial [astrology], he was the most singular man ever known. The things that he says on this matter are appalling. But of no consequence for us". ${ }^{61}$ Moreover, Vera Cruz himself had written a text, which has been lost, with the unequivocal title Contra iudiciariam astrologiam in 1572, four years before Rada's letter containing the list of what he was working on. ${ }^{62}$

6o "V. p. me embió a pedir si tenia alguna obra hecha. Como algunas que tenia se me avian perdido, yo escrevi un libro De recta hydrographie ratione, y avia escripto gran parte De geometria practica en romançe, por parescerme que no ha salido desta materia en romançe cosa de ver, y va distinta en siete libros. Y despues pensava escrevir otros siete de cosmographia y astronomia. Y los años passados escrevi de astrologia judiciaria, del qual libro me ha quedado el borrador. No he cargado tanto el juicio sobre este por no serme parescer cosa decente a religioso, aunque bien podriamos defenderla de los que inméritamente la impugnan. Tambien escrivi un libro de toda manera de hazer relojes. De todo esto, si a V. p. le parescia ser cosa que es justo que nos ocupemos en hazer, procurare de trabajar, que mucho me ha quitado el animo ver mis trabajos perdidos por estos mares", Rada, "Carta a fray Alonso de la Vera Cruz, Manila, 3 de junio de 1576", BNF, Fonds Espagnol, M F 13184, 325.7, fols. 35-36.

61 "En esto de la judiciaria fue el más singular hombre que se ha conocido. Las cosas que de él se cuentan en esta materia son espantosas. Pero para nosotros de ninguna consecuencia", Grijalva, Crónica, 243.

Burrus, Vera Cruz's writings, vol. v, 345. 
The interest of both Vera Cruz and Rada in clocks deserves particular attention. Vera Cruz had added orologios to the scientific materials in his library and Rada stated that he wanted to write a book about clocks, and, without a doubt, his interest centred on the usefulness of mechanical clocks for geographical measurements. Beyond that however, clocks had become a hallmark of the refined European upper classes: Lorenzetti had already introduced the clock as an attribute of temperance in his monumental fresco in Siena, Il Buon Governo, and, in the 16th century, Titian painted the mechanical table clock as a highly distinctive seigneurial complement. ${ }^{63}$ At the end of the century, clocks always appeared in the many lists of presents prepared at the court of Philip II to send to the Chinese emperor, described as "clocks for the king and his governors", ${ }^{4}$ or as "some seat clocks that run on weights". ${ }^{65}$ This present from Philip II was never sent, just as the one planned by the Jesuits Valignano, Ruggieri, and Ricci as a present from the pope in 1588 was not, which was also envisioned as "a timepiece [...] to have on the table". 66 When a present was finally sent to the emperor by Matteo Ricci and Diego de Pantoja in 1602, it included "two gear clocks".67 The advantage of these clocks was that no one at court knew how to make them work so they cleared the way for missionaries to remain at court to maintain the clocks. Even so, it would be centuries before Chinese society generated a demand for European-style clocks given that the division of the hours into halves, quarters, minutes, and seconds was totally alien to the traditional Chinese method of telling time.

Likewise, nothing has been preserved of Rada's linguistic works. Like Vera Cruz, who had concentrated on the Tarasca or Purépecha language, Rada focused on the language of the Otomí, one of the most ancient peoples of Mexico, and probably composed some Sermones Morales in the language, which were kept in the monastery of San Pablo de México until they were

63 Titian, Retrato de Fabrizio Salvareso, 1558, in the Kunsthistorisches Museum, Vienna.

64 "Reloxes para el rey y sus gobernadores", Consejo de Indias, "Memoria de las cosas que su Magestad debe enviar al Rey de Taybin [1580]", AGI, Patronato, 25, R. 3.

65 "Algunos reloxes de pesas y de asiento", Ronquillo, Gonzalo de, "Memoria de las cosas que se careçe en la China y serán muy estimadas en ella [1578]", AG I, Indiferente, 1956, L. 2, fol. 114. Both references are found in Wang Romero, "Las listas de la compra ¿Qué le regalamos a un emperador chino?", $15^{2-53}$.

66 "Un relox de horas [...] para se tener en una mesa”, Ricci, Ruggieri, Valignano, “Memorandum de las cosas que han de venir para el presente que Su Santidad ha de embiar al Rey de la China [1588]", Archivum Romanum Societatis Iesu (ARSI), Fondo Gesuitico, 722/2.

67 "Dos reloxes de ruedas", Moncó, Relación de la entrada de algunos padres de la Compañía de Jesús en China, 109. 
confiscated in 1861, ${ }^{68}$ and an Arte de la lengua otomí. ${ }^{69}$ González de Mendoza maintained that he also wrote an Arte y Vocabulario de la lengua china which has not been found..$^{70}$ And so, little is known about the whereabouts of Rada's works or even if they have survived. Some researchers claim that they saw some of his linguistic works in monasteries in the Philippines during the 19th century, ${ }^{71}$ but the only thing that is certain is that some of Rada's papers were in the monastery of San Pablo in Mexico at the end of the 17 th century. ${ }^{72}$

\section{Sharing the Critical Perspective on the Conquest with Their} Salamanca Masters

Both Vera Cruz and Rada criticised the methods used in the conquest of America but in different ways. Vera Cruz arrived in Mexico in 1536 when the great conquests had already taken place and the vast riches that resulted from them had gushed into Castile. The problem was twofold: firstly, how to organise the civil and ecclesiastical administration of the territory and secondly, how to organise the work and the tributes of the Natives without excessively exploiting them, "there began such cruel mortality that, of six parts of the Indians, five are missing",73 thus leaving an administration with no one to administer to.

Like Vitoria before him, Vera Cruz questioned the very legitimacy of the way in which the conquests were being carried out, focusing especially on the seizure of the natives' goods,

I beg you, good reader, to put aside all prejudice and reflect by what law, by what right, did the Spaniard who came to these regions, armed to the teeth, attack these people, subduing them as though they were enemies

68 Castro, Osario venerable, 221-222.

69 Goodrich and Fang, Dictionary of Ming Biography, vol. II, 1131. A contemporary of Rada, Antonio de Acebedo, left written evidence in 1589 of the existence of this Arte by Martin de Rada, Galende, Martín de Rada, 45 and n. 7 .

70 Two books with this title exist in Spanish libraries, one is in the library of the Augustinian Order in Valladolid and the other is in the library of the University of Barcelona. Both of them are from the 17th century and each one has been studied, the first by Van der Loon (The Manila Incunabula and Early Hokkien Studies) in 1967 and the other by the present author in 1995, Folch, "Sinological Materials in Some Spanish Libraries".

71 Vela, Ensayo de una biblioteca Ibero-Americana de la Orden de San Agustín, Vol. VI, 448-452.

72 San Agustín, Conquistas de las islas Philipinas, 362.

73 "Empezó tan cruel mortandad, que de seis partes de indios faltaron las cinco", Grijalva, Crónica, 145 . 
and occupying lands [that were] not their own, arbitrarily seeking out all their valuable possessions and robbing them with force and violence? I do not see [by what law or right], perhaps I am falling apart in the strong sun. ${ }^{74}$

He also insistently called for the things that had been stolen from the Natives to be returned to them but, vehement as his criticism were, his overall effort tended towards rationalising the fait accompli of the conquest in the best possible way. He also took into account the fact that the instruction of indigenous peoples in the Christian faith would probably be interrupted if the Spaniards abandoned the New World or if the emperor (Charles v) restored the former rulers to their offices. Vera Cruz could see no alternative to maintaining and progressively improving the political status quo.

And because one must act in these broad conjunctures and there is the probable risk that, if the emperor abandoned this New World to be governed by its former rulers, they would return to their former abominations owing to their inconstancy and coarseness and because the faith has not yet become firmly rooted, [and so] the emperor justly keeps them under his rule so that they too can attain the life for which they were created..$^{75}$

But even if he followed the model of valid and invalid titles previously developed by Vitoria, Vera Cruz's position differed significantly from that of his master. In his treatise De dominio infidelium et iusto bello, he revisited the main justifications that Vitoria had cited in favour of waging war against the Natives and although he considered them valid in general terms from a legal perspective, he rejected their applicability to the American context, that is to say their de facto validity.

74 "Obsecro, pie lector, omni deposito affectu, considera qua lege, qua ratione poterat Hispanus qui ad istas appulit terras, armis onustus, aggrediens istos non alias hostes, nec alienam terram ocupantes, subiugando pro libitu, petere et vi et violentia sua quaeque pretiosa, et eos exspoliare? Ego non video; fortassis in medio sole decutio!", Vera Cruz, Relectio de dominio infidelium, in Burrus, Vera Cruz's writings, vol. II, 162-163.

75 "Et quia in istis grossis coniecturis agendum est, et timor est probabilis quod, si imperator istum Novum Orbum reliquisset gubernandum regibus antiquis, ad vomitum reverterentur propter eorum inconstantiam et rusticitatem; et quia fides nondum in profundum misit radices, iuste imperator retinet eos sub imperio conclusos ut sic vitam ad quam sunt creati etiam consequantur", Vera Cruz, Relectio de dominio infidelium, in Burrus, Vera Cruz's writings, vol. II, 26o-261. 
For example, in some of his final conclusions (Doubt XI, Conclusions $\mathrm{XII}-\mathrm{XV}$ ), he engaged with the rights of communication, commerce, mineral exploitation, and the peaceful presence of the Spaniards in the Western Indies, something that Vitoria had already repeatedly advocated for and which strongly highlights the colonial interests in Salmantine thought.

If some unbelievers, regardless of their rank, were not to allow the Spaniards to move among them at will, supposing the latter desired to do so without harming the natives, the Spaniards might enforce their right by war [...] If the Spanish believers were forbidden by the inhabitants of the New World to engage in trade, they might lawfully defend themselves and even avenge the wrong by war [...] If the Spaniards acted peacefully, as travellers and strangers are wont to conduct themselves, and desired to dig for metals and extract silver and gold from the mines and precious stones from common lands, should the inhabitants forbid them to do so, the Spaniards might resist them because of the injustice done to them. ${ }^{76}$

Vera Cruz granted the Spaniards nothing more than the rights to travel and trade which natural law and the law of nations gave to all men as political animals. ${ }^{77}$ Nevertheless, the Augustinian friar consciously and carefully made these rights dependent always on the peaceful conduct of the travellers sojourning in foreign countries and insisted throughout his Relectio that the de facto behaviour of the Spaniards in the Western Indies, ${ }^{78}$ which was full of

${ }_{7} 6$ "Si aliqui infideles cuiuscumque sint condicionis, Hispanos non permitterent apud se peregrinari, si id absque illorum detrimento vellent, possent bello compelli [...]. Si fideles Hispani a negotiatione prohibeantur ab incolis huius Novi Orbis, licite possunt se defendere et etiam bello talem iniuriam vindicare [...]. Si Hispani pacifice agentes, sicunt solent peregrini et advenae, vellent istorum fodere mineralia, et argentum ex ipsis eruere, et aurum ex aurifodinis extrahere, et lapides pretiosos ex locis publicis et communibus omnibus, et ab incolis prohiberentur, possent agere Hispani contra eos ratione iniuriarum", Vera Cruz, Relectio de dominio infidelium, in Burrus, Vera Cruz's writings, vol. II, $448-449,454-455$, 457. One of the first comparisons between the positions of Vitoria and Vera Cruz can be found in Cerezo de Diego, Alonso de Veracruz y el derecho de gentes, 444. "Patet: quia peregrinatio, vel iure naturae est, vel saltem iure gentium, quod proxime ad ius naturale accedit. Patet: quia homo est naturaliter animal politicum", Vera Cruz, Relectio de dominio infidelium, in Burrus, Vera Cruz's writings, vol. II, 45o.

78 "Dixi in conclusione "quando talis peregrinatio fit absque iniuria ipsorum infidelium". Nam, si per tales peregrinos deberet suae reipublicae pax perturbari, vel aliquod aliud damnum pati, non tenerentur ad talem hospitalitatem; vel, si in bonis temporalibus deberent pati damnum", Vera Cruz, Relectio De dominio infidelium, in Burrus, Vera Cruz's writings, vol. II, $45^{2}$. 
abuses and arbitrary violence, not only made whatever right the settlers could appeal to null and void, but also justified the attacks of the natives, presented by Vera Cruz as legitimate self-defence.

But if, perchance, the inhabitants of the New World upon seeing the armed soldiers and fearing that the mighty Spaniards were not coming for the purpose of traveling around but of spying and plundering and conquering their domain, and if, in their desire to provide for their own safety, they did not allow the Spaniards to enter, under such circumstances they would be doing the Spaniards no injustice by defending themselves. ${ }^{79}$

Rada moved in other circles and intervened even more critically in the debate on the just titles. He arrived in the Philippines in 1565 and observed for years how very poor natives found themselves pillaged without the perpetrators actually gaining much out of it. The very day of his arrival, before the consultation to decide if it was correct to land using force which was convoked by Legazpi - another student at Salamanca who arrived with royal instructions steeped in the ius gentium advocated by Vitoria $-{ }^{80}$ he witnessed how the just titles so advocated by Vitoria and Vera Cruz were pulverised before his very eyes, while the booty, unlike that of Mexico, was limited to a brace of hens.

Father Urdaneta spoke first and responded that natural law granted them that the armada should not perish, that it was done for the good of those barbarians to look for food by any means [...] and that it was wilfully injurious to refuse to trade [...] and that it was therefore valid to take up arms and look for the food they unjustly denied them, Quibus necessarium, justum est bellum. And so, it seemed to him that the war was just and that it had only to be justified by some means, following firstly the procedures and setting the requirements for peace $[. .$.$] at the noise of the guns, the$ Indians fled and the captain was able to round up some wretched-looking cattle that were there and some Castilian hens. ${ }^{81}$

79 "Sed tamen, si forte incolae huius Orbis inermes, videntes armatos milites et robustos Hispanos, timentes non venire causa peregrinationis sed explorandi, exspoliandi et dominandi, et, sibi providentes non concederent ingressum, in tali casu, non facerent iniuriam Hispanis se defendendo", Vera Cruz, Relectio De dominio infidelium, in Burrus, Vera Cruz's writings, vol. II, $45^{2}$.

8o Mojarro, "La defensa del indio en la temprana literatura hispano-filipina colonial", 25.

81 "El padre Urdaneta habló primero y respondió que el derecho natural les concedía, para que no pereciese aquella armada, que se había hecho para bien de aquellos bárbaros, 
In any case, the vast majority of those who disembarked in the Philippines, some 200 soldiers, knew nothing about any just title and it did not worry them in the least. Even Grijalva, an educated Augustinian writing 50 years later, sidestepped the subject with complete peace of mind.

Rash is he scruples over the right our monarchs have to all these provinces and that which the conquistadores have to make war because they did it to increase the revenues of their sovereigns. It is not for the soldier to investigate the justification for the war, as all the doctors conclude, it is enough that he does not believe it to be patently unjust and that he holds his king to be so Catholic and good that he would not wage war on anyone without having every justification. The reasons that Father Urdaneta gave in two consultations seem very good to me, but for soldiers it is better that we close with the conclusive reason that, by grant of the pope, [...] those islands belong to our Catholic Monarchs of Castile and León. And therefore their people can make port wherever they will, request supplies in exchange for their money, found towns and cities, raise castles as in their own land, and make war on those who say otherwise as they do so unjustifiably. ${ }^{82}$

The first issue that was raised here was directed to those who were concerned about the Natives and it intended to shed light on their nature, a subject which provoked highly disparate views across Spain in the 1530s. While

buscase la comida por el camino que pudiese [...] y que era injuria conocida negarse al comercio [...] y que era lícito por ello el tomar las armas, para con ellas buscar comida que injustamente les negaban. Quibus necessarium, justum est bellum. De manera que le parecía que era justa la guerra, y que solo se debía justificar por algunos medios, haciendo primero diligencias y requerimientos de paz [...] al ruido de las escopetas huyeron los indios y el Capitán pudo recoger algún ganado prieto que por allí había y algunas gallinas de Castilla", Grijalva, Crónica, 251.

82 "Temerario es el que escrupulea en el derecho que nuestros reyes tienen a todas estas provincias, y en el que tuvieron los conquistadores para hacerles guerra, pues la hacían para cobrar la hacienda de sus reyes. El soldado no ha de averiguar la justificación de la guerra, como concluyen todos los doctores; basta que no la tenga por injusta declaradamente y que tenga su rey por tan católico y bueno que no movería guerra a nadie sin tenerla muy justificada. Muy bien me parecen las razones que en dos consultas ha dado el padre Urdaneta: pero para soldados mejor es que nos cerremos con esta razón concluyente, de que por concesión del Papa [...] aquellas islas son de nuestros católicos reyes de Castilla y de León. Así pueden los suyos tomar puerto donde quisieren, pedir bastimentos por sus dineros, fundar villas y ciudades, levantar castillos como en su propia tierra y hacer guerra a los que le contradijeren, pues les contradijeren injustamente", Grijalva, Crónica, 254. 
for Las Casas the Natives were "people without evil and without guile [...], most obedient and faithful [...] Nor are they quarrelsome, rancorous, querulous or vengeful", for Gonzalo Fernández de Oviedo they were "naturally lazy and vicious, melancholic, cowardly, and in general a lying, shiftless people", who wanted "to eat, drink, worship heathen idols, and commit bestial obscenities".83

From Salamanca, first Vitoria and then Soto intervened with vehemence in defending the fully human condition and the natural qualities of the Natives as evidenced by their proven ability to live peacefully, form their own governments, and administer the territories under their rule, living partially under the first principles of natural law. ${ }^{84}$ Vera Cruz followed in their footsteps, his De dominio infidelum et iusto bello unflinchingly examined the actual workings of the encomiendas and the colonial administration, something which neither Vitoria nor his companions at Salamanca entered into. ${ }^{85}$ His highly positive opinion about the rational capacity of the Natives expressed itself in his desire to administer the sacrament of the Eucharist to them, something which scandalised the ecclesiastical authorities in Mexico, ${ }^{86}$ and of publishing his Speculum coniugiorum as a defence of the validity of the marriages the natives had contracted before their conversion to Christianity, even if some of their customs and traditional rites were far removed from contemporary European practices. ${ }^{87}$

83 Hanke, The Spanish Struggle for Justice in the Conquest of America, 11.

84 "Patet quia habent ordinem aliquem in suis rebus, postquam habent civitates etc, et habent matrimonia, magistratus et dominos, leges, opificia, commutationes; quae omnia requirunt usum rationis; item religionis speciem, etc. Item non errant in rebus, quae aliis sunt evidentes; quod est indicium usus rationis", Vitoria, De Indis, 562. "Et per hac satisfieri illis debet, qui sciscitantur utrum iure naturalis dominii possimus Christiani infideles armis infestare, qui pro suorum morum ruditate, naturales videntur esse servi. Nullum enim inde ius contra eos acquirimus vi illos subiugandi [...] Sed de hoc latius in libello nostro De ratione promulgandi Evangelium: ubi de dominio \& iure quo catholici Reges in Novuum Orbem oceanicum funguntur, amplior patebit dicendi locus", Soto, De iustitia et iure, L. IV, q. 4, a. 2, "Utrum homo hominis dominus esse poßit", 290.

85 Vera Cruz analysed the exaction of tributes by the encomenderos, native caciques, and royal officers and the kind of religious instruction that the Natives were receiving in exchange for their subjugation in Doubts I-IV of his Relectio. On the similarities and differences between the approaches of Vera Cruz and his Salamanca masters, see Pereña, $L a$ Escuela de Salamanca, 97.

86 On this issue, see Rubial García, "Fray Alonso de la Veracruz, agustino", 85.

87 "Inter infideles in novo orbe erat legitimum matrimonium, ubi coniuncti fuerunt secundum mores suos vir, et foemina, voluntarie, ad prolis procreationem: et operum communicationem", Vera Cruz, Speculum coniugiorum, L. II, Art. II, "Utrum inter infideles Novi Orbis sit matrimonium", 92. 
For his part Rada, who was perfectly capable of evaluating an alien culture and indeed returned from China with a highly positive general impression of the country, had absolutely no doubt as to the rational capabilities of the native Filipinos, describing them with evident disdain.

They do not attempt to lay up stores and are the most indolent people in the world, [...] and beyond that they have so little loyalty to one another that, even though they may be relations or brothers, when coming across each other in the open, the one most able to do so turns on the other and overwhelms him. [...] The people of these islands are without either a king or lord, the majority of them without law, and some are easy to convert and take our faith like monkeys, most desirous to imitate us in dress and speech and everything else. ${ }^{88}$

Rada wrote a letter to Vera Cruz on the customs of the Natives, clearly concerned that his disparagement of them would annoy Vera Cruz, he began the letter by saying that he was going "to give an account to Y.f. of the customs of the Natives and of the things of this land as Y.f. commands me. Although in previous years I was determined not to speak of it, ${ }^{89}$ people credit more what is commonly said than what is written from here". ${ }^{90}$ It is a long letter in which, after stating that "All the peoples of these islands are very barbaric and although learned, without political order", he went on to describe in detail the local inclination for theft, "if they find the occasion, they rob entire villages for absolutely no reason because they are neither enemies nor have they done

88 "No procuran de atesorar, y es la gente más aragana que ay en el mundo, [...] y allende desto, por la poca lealtad que se guardan vnos a otros, que, aunque sean parientes o hermanos, en topándose en descampado, el que más puede prende al otro y lo rrescata.[...] La gente destas yslas son sin rrey ni señor, sin ley los más dellos y algunos fáçiles para convertirse y tomar nuestra fee, antes como monos deseosísimos de ymitarnos en el traxe y en la abla y en todo lo demás", "Carta del P. Martín de Rada al Virrey de México, Cebú, 8 de julio de 1569", AGI, Filipinas, 79.

89 In Mexico and in Spain.

9o "A dar cuenta a V.p. de las costumbres de los naturales y de las cosas desta tierra como V.p. me lo manda. Aunque estava los años passados determinado de no hablar sobre ello pues alla dan mas credito al dicho del vulgo que a lo que de aca se escribe [...] La gente toda destas yslas es gente muy barbara aunque entendida, pero sin orden ni conciertos de policía [...], si hallan ocasion roban pueblos enteros,y esto sin ocasion ninguna porque ni son enemigos ni ha rescebido dellos mal ninguno, sino por solo robar que es essa su costumbre [...], sus guerras dellos nunca son sino de salteadores", Rada, "Carta a fray Alonso de la Vera Cruz, Calompit, 16 de julio de 1577”, BNF, Fonds Espagnol, M F 13184, 325.8, fols. $37-38$. 
them any harm but rather only for the sake of stealing, this being their way". He further claimed that the chaos from this indiscriminate pillaging caused "their wars, in which they are never anything more than raiders" and generated a multitude of slaves. This negative perception that Rada had is in direct contrast to other contemporary impressions, such as that of Miguel de Loarca, a close companion of Rada in their journey to China, who was the author of the Tratado de las Yslas Philipinas (1582), ${ }^{91}$ a refreshing and very important ethnology that covered the main islands of the Philippines individually.

Just because Rada had a very tepid opinion of the natives does not mean that he did not raise his voice indignantly against the abuses they were subjected to.

We the Spanish are vilified in this land and our name abhorred, even that of the most holy name of our Lord, as usurpers of what belongs to others, faithless corsairs, and shedders of human blood because they see that we mistreat, harass, work, and subject even our own friends to much violence and force, doing so in their very houses to their wives, and daughters, and property, and mistreating their persons in word and deed. ${ }^{92}$

The problem was not limited to the Natives, it also translated into a destruction of resources, calling into question the conquest itself, which was now, by decree, called pacification. ${ }^{93}$ Rada gave a searing report of the disastrous consequences that had been unleashed by so much abuse.

Many islands and peoples are destroyed and almost ravaged partly by the Spanish or for their sake, partly by famine, which was occasioned directly or indirectly by the Spanish when they ceased sowing either through fear or to dislodge the Spaniards and, when they wanted to sow, locusts came and so many people died of hunger. ${ }^{94}$

91 Loarca, Tratado de las Yslas Philippinas, Colección Muñoz, A/107, Ms 9/4842, fols. 267r299r. In Robertson, Blair, The Philippine Islands, 1493-1803, Vol. v, 1582-83, 34-187.

92 "Estamos los españoles ynfamados en esta tierra y aborreçido nuestro nombre, y aún el sanctísimo nombre de nuestro señor, como vsurpadores de lo ageno, corsarios sin fee y derramadores de sangre humana, porque veen que aún a nuestros mismos amigos los maltratamos, acosamos, travajamos, y se les hazen muchas violencias y fuerças, así en sus casas, como en mugeres e hijas y hazienda y maltratando sus personas con palabras y obras", Herrera, Rada “Memoria de los Religiosos de las yslas del poniente, Manila, [1572]”, AGI, Filipinas, 84 .

93 See the almost contemporary Ordenanzas de descubrimiento, nueva población y pacificación de las Indias, Bosque de Segovia, 13 de julio de 1573.

94 "Muchas yslas y pueblos están destruydos y casi asolados, parte por los españoles o por su causa, parte por ambres, de las quales o de su principio dellas fueron ocasión 
These sentiments were also expressed by another Augustinians in the Philippines, Fray Diego de Herrera, a man of great character who was probably the most critical of all.

Everything was destroyed in no time at all because the way that things have been so far $[. .$.$] is to rob the natives and burn their villages and make$ slaves of them or, if not, to claim that they cannot support themselves, which is untrue. They cannot support themselves in these circumstances because they are destroying everything, and they harass the natives to the point of leaving them without a moment's peace. ${ }^{95}$

The version of the settlement of the Philippines that the Augustinians sent to the king was completely different from the one painted by Legazpi and the colonial administration, both versions being based on powerful interests. The image of the Philippines as the epitome of good government and peaceful and loyal Natives reinforced the role of the colonial administration and justified the positions and remuneration that the king provided ${ }^{96}$ while the systematic robbery and abuse of the Natives, together with the disorder and poverty into which the islands had sunk, facilitated an increase in the ecclesiastical share of power in the new lands.

Even if the realities in which they were immersed differed for Vera Cruz and Rada, both were former students of Salamanca and must have wondered about the just title Spain had to conquer the New World. Vera Cruz, following in the footsteps of Vitoria, would take apart the titles that justified the conquest one by one, not only in the previously mentioned Relectio de dominio infidelium, but also in drafts and reports, such as a Parecer razonado given to another friar travelling to Spain and acting as procurador of the Augustinians there.

los españoles, que o por miedo o por desechar los españoles dexavan de sembrar, y quando quisieron sembrar sobrevino langosta, y así á muerto mucha gente de hambre", Herrera, Rada "Memoria de los Religiosos de las yslas del poniente, Manila, [1572]", AGI, Filipinas, 84 .

95 "Destruirse à todo en muy breve tiempo, porque el modo que hasta agora se tiene [...] es robar a los naturales y quemarles los pueblos y hazerlos esclavos, y si no haciendo esto afirman que no se pueden sustentar, lo qual es falso, antes de esta manera no se pueden sustentar, porque lo van asolando todo y traen tan acosados a los naturales que no los dexan un momento [...]", Herrera, "Carta de fray Diego de Herrera a Felipe II, Manila, 25 de Julio de 1570", in Rodríguez, Historia de la Provincia agustiniana del Santísimo Nombre de Jesús de Filipinas, vol. xIV, 55 .

96 See Folger, Writing as Poaching, 18-50. 
It is not enough that they are pagans to [justify] depriving the native kings of their titles and the lords of their jurisdiction and then subject them to others as taxpaying vassals of new rulers if these rulers live peacefully and do not harm the Christians or the Spanish dominions [...] Nor may the pope confer such a title or grant to authorise the kings of Spain, inasmuch as no one can give what he does not have [...] The only title, then that his Majesty possesses over them is this, that all the Indians or a majority of them desire to become his subjects of their own free will and consider themselves honoured to be so. ${ }^{97}$

Rada took up this theme again in his letter of 16 July 1577 to Vera Cruz in which he explained his position in detail, ${ }^{98}$

[...] some of the reasons why it was possible to subjugate this land with a just title: [...] The first is that put forward by Victoria as the fifth legitimate title, ${ }^{99}$ his words being "Propter tyrannidem vel ipsorum dominorum vel etiam propter leges tirannicas in injuriam innocentum, puta quia sacrificant homines" [On account of the tyranny of the lords themselves or on account of tyrranical laws that injure the innocent, because they sacrifice men], ${ }^{100}$ and I have nothing to add, as he puts it very clearly there. $[\ldots]$ The second, ${ }^{101}$ to secure both the sea and land routes [...] because in this land it was not safe anywhere even for the natives themselves to go

97 "Para despojar a los reyes de sus títulos, a los señores de sus señoríos [...] no basta que sean infieles, viviendo ellos en paz y sin haçer daño a los christianos y a los reynos de España. [...] Tampoco el papa puede dar tal título ni licencia a los reyes de España: nadie puede dar lo que no tiene. [...] El título que S.M. tiene es solo este: que los indios, todos o la mayor parte, de su voluntad quieren ser sus vasallos [...]", Vera Cruz, "Parecer razonado sobre el título de dominio del Rey de España sobre las personas y tierras de indios”, in Burrus, Vera Cruz's writings, vol. I, 77-85.

98 Rada, "Carta a fray Alonso de la Vera Cruz, Calompit, 16 de julio de 1577", BNF, Fonds Espagnol, M F 13184, 325.8, fols. 37-38.

99 Rada may have taken some writings of Vitoria to the Philippines or he may have known them by heart.

100 "Algunas de las razones por do esta tierra con justo titulo podia aver sido subjectada: [...] El primero es el que pone Victoria por título quinto legítimo que son sus palabras Propter tyrannidem vel ipsorum dominorum vel etiam propter leges tirannicas in injuriam innocentum, puta quia sacrificant homines. Y en este no me alargo pues alli lo pone bien claro". In fact, the fifth title of Vitoria referred to tyranny and cruelty of the rulers that is against nature.

101 "El segundo, por assegurar los caminos, assi de mar como de la tierra. [...] Pues en esta tierra, en ninguna parte della, les era seguro, aun a los mismos naturales, el yr de una parte a otra". Here, Rada referred to Vitoria's first title. 
from one place to another. [...] It is possible to give another third title to justify subjugating them [...] by free will and licit preaching of the Gospel among them, and Vitoria puts this as the second true title, although he says that all means possible should first be attempted to get the preachers in [...] and if I remember correctly, Soto [had this as his] fourth [title] [...] And so this alone provides a reason for war: to be able to preach the name of Christ safely among them. ${ }^{102}$ I have no need to expand on this to prove it when writing to Y.f., who is the master of all. [...] Other reasons could be given such as they are not a people capable of constructing a reasonable republic, that they have neither lords nor kings but rather every little village, no matter how small, is a republic unto itself. ${ }^{103}$

Rada's letter mentioned Vitoria's writings in enough detail to suggest that he knew them by heart, Soto with much less precision, and he called Vera Cruz an unequivocal master. He further demonstrated how the debates about the just titles, which Grijalva blithely shook off, continued to be a vital topic in academic and ecclesiastical circles. Finally, Vitoria, Vera Cruz, and Rada all agreed that the conquest may have been just but that it was carried out badly and for the wrong reasons and that what was important now was not to undo the conquest but rather to undo the damage.

The crux of the problem was in the permanence of the encomiendas. At one point, Vera Cruz argued for the outright abolition of the repartimientos de indios, citing the evils inflicted on the Natives and the political danger that the encomiendas represented for the authority of the Spanish kings over the recently conquered lands in America and Asia.

H.M. is obliged to free those [Natives] held in trust inasmuch as they were entrusted to the encomenderos not to be robbed by them, as is happening, or forced into personal service, but rather they were entrusted [to them] to be instructed in the law of God [...], they should be freed, inasmuch as

102 "Otro tercer titulo se podia dar por donde fuesse justo el subjectar a estos [...] por poder libre y licitamente predicar el evangelio entre estos, y este pone por segundo titulo verdadero el Vitoria, aunque pone que primero se prueve por todas vias que se admittan los predicadores [...] aunque si bien se me acuerda, Soto, en el quarto [...] Y assi, esta sola da causa de la guerra: de poder con seguridad predicarse entre ellos el nombre de Christo. No tengo que estenderme a provar esta parte escriviendo a V.p., que es el maestro de todos".

103 "Otras causas se podrian dar de que no es gente para poder constituyr razonable republica, que no tienen señores ni reyes, sino que cada pueblezillo por chiquito que sea es republica por si". A reference to Vitoria's eighth title appears here: that the barbarians are incapable of constituting and administering a republic. 
they will be better instructed by others because they now have bishops and preachers who are obliged to teach them the law of the Gospel [...] it is vitally important to your Majesty's government that these Indians not be scattered and parcelled out because by giving them to these overlords, each one of them will consider himself a king. These men do not love the king, nor do they seek to enhance the royal Crown of Spain, but rather advance themselves and their house. And since they are so far away, they are on a point of stirring up a revolt in the land. As the experience of a few years ago has shown, neither the lords nor the encomenderos keep this country loyal, but rather provide the occasion for it to rebel. ${ }^{104}$

Even so, both Vera Cruz and Rada agreed that, however things stood, the encomiendas were untouchable. Vera Cruz said as much in his response to Tello de Sandoval, who had been sent from Spain to look into how the Leyes Nuevas were being applied in Mexico.

The first thing [is to examine] whether or not it is conducive to the service of God and his Majesty, and the welfare and progress of this land and its preservation that the villages of the Indians should remain in trust as until now [...]. Firstly, we say that this institution not only seems to be expedient but even necessary for the preservation of this land, for the increase of the faith, for the security of Christianity, and the prosperity of your Majesty inasmuch as it is imperative that the Spaniards are won over by personal interests which result in the advantage of their children in order to overcome their natural attachment to their home country with temporal gains. ${ }^{105}$

104 "S.M. es obligado a los quitar [a los indios] a aquellos que los tienen en encomienda, porque les fueron encomendados no para los robar, como lo hacen, ni para se servir de ellos, sino para que les enseñasen la ley de Dios [...]. Hay que quitar las encomiendas porque de otros seran mejor enseñados, pues ya tienen obispos y predicadores a quien de ley evangélica incumbe enseñar [...] Que no sean los indios distribuidos y repartidos, mucho importa al estado real de S.M. Porque en dándoles señores luego cada uno de ellos se terná por rey. Y, como no aman al rey, ni al aumento de la corona real de España, sino el suyo propio y de su casa, con estar tan a trasmano estan a dos pasos de se levantar con la tierra. Como la experiencia lo ha desmostrado de pocos años acá: que ni los señores ni los encomenderos aseguran la tierra, antes la ponen en ocasión de se alçar", Vera Cruz, "Parecer razonado sobre el título de dominio del Rey de España sobre las personas y tierras de indios", in Burrus, Vera Cruz's writings, vol. I, 87.

105 "Lo primero, si es cosa conveniente al servicio de Dios e de S.M. y bien e aumento de esta tierra y perpetuaçion de ella, que aya pueblos de indios encomendados como hasta aquí los avía vido o no [...]. Dezimos que no solamente nos pareze ser conveniente, mas 
The letter was signed by, among others, Alonso de la Vera Cruz, Juan Cruzat (Rada's relation), and Juan de Alva, who would become Rada's companion in the Philippines.

In one of his letters to Vera Cruz, Rada referred to and supported the opinion held by Vera Cruz that the encomiendas should remain in force.

When all is said and done, for better or worse, the land has already been conquered and tributes collected throughout for some years. It seems to me, salvo meliori judicio, ${ }^{106}$ that this land could be conquered with just titles, which I shall write about another time to Y.f. should you command me to do so. And [also about] if its conquest and remaining here is just, even if the conquest was badly carried out and with faulty title. [...] And, even if the conquest was illicit, it is not at all right to abandon it now, as Y.f. writes so well. ${ }^{107}$

In short, as Rada said, "It is better to try to fix what is cracked than to break it completely". 108

One problem stemming from the encomiendas was the confession of the encomenderos. Confession manuals, of which various had been published in Mexico, instructed that Communion should be withheld from encomenderos who did not relinquish their encomiendas and make restitution for all that they had stolen. In a long letter responding to one of Vera Cruz's, now lost, which appears to have asked Rada to deny them absolution, Rada defended himself, alarmed by what he believed to be the unjustified bad reputation that the

aun nesçesaria para la conservaçión desta tierra, ansí en el aumento de la fee como para la seguridad de christianismo y pro de la hazienda de S.M.; porques nezesario que los españoles se enamoren, con particulares yntereses que rredunden en sus hijos, para perder el apetito natural de la patria, con el probecho temporal de esta tierra", "Parecer que dieron los religiosos de la orden de Santo Agustín en la Nueva España, estando en ella el licenciado Tello de Sandoval, 1544", in Burrus, Vera Cruz's writings, vol. v, 103-105.

106 "Barring better judgment".

107 Rada seems to be referring to another of Vera Cruz's letters, now lost.

108 "Pero en fin mal o bien ya esta conquistada la tierra, y se cobran tributos de toda ella algunos años ha. A mi me paresce, salvo meliorijudicio, que esta tierra se pudo conquistar por justos titulos, de lo qual escrivire en otra a V. p., pues assi me lo manda. Y, si justamente se pudo conquistar, tambien retener, aunque la conquista fuesse mal hecha y con mal titulo. [...] Y, aunque fuera ilícita la conquista, agora no es justo desampararlos por ninguna via, como V. p. tan bien lo escribe [...] Mas vale lo que está cascado procurar de sustentarlo que quebrarlo del todo", Rada, "Carta a fray Alonso de la Vera Cruz, Calompit, 16 de julio de 1577", BNF, Fonds Espagnol, M F 13184, 325.8, fols. 37-38. 
Philippines had gained in Mexico, and set out the reality of the local situation, advocating for the absolution of the encomenderos without obliging them to make restitution, given that many of the encomiendas were very poor.

I received the [letter] of Y.f. who advised us with paternal encouragement not to stray from the paths of righteousness by absolving persons in a bad state. [...] And even if there, ${ }^{109}$ they greatly exaggerate the bad order and bad conquest as perverse and abominable, given the quality of the people, it is not as bad as is imagined. For better or worse, the islands are already conquered [...] Being on the spot and not knowing how to give them a solution is very different from speaking from afar [...]. I say this because they have written to us to say that encomenderos cannot be absolved unless they relinquish their encomiendas and make restitution for what they have taken. To this I say that if the land is to be sustained, it is better for the Indians themselves that there are encomenderos rather than not. [...] As to restitution, there is no encomienda, except [perhaps] six or eight, which can return anything $[\ldots]$ and most would give what they have in order to get a licence to leave the land. And so, the great necessities that have come to pass and the many that happen and the misery of the land, and because they have no other way of supporting themselves and are not able to leave the land, and because it is impossible to make restitution, along with the knowledge of their misery and desire to be redeemed, mean that they can be absolved.110

109 "There" meaning New Spain/Mexico.

110 "La de V. p. rescebi, do con animo paternal nos avisa que no nos perdamos por absolver al que está en mal estado. [...] Y aunque por ay encarescen tanto la mala orden, y conquista mala, perversa y abominable fue, pero segun la qualidad de la gente no es tanto como por alli se ymagina. Ya las islas bien por mal estan conquistadas [...] Es muy differente hallarse metido en la massa y no saver darles remedio o hablar desde fuera [...]. Digo esto a proposito de que ay nos escrivieron que los comenderos, si no dexavan las encomiendas y restituyan lo que hasta agora avian llevado, que no podian ser absueltos. A lo qual digo que si la tierra se ha de sustentar, mejor es para los mismos indios que aya encomenderos que no que no los aya. [...] En lo de restituir, no ay encomienda que pueda restituyr nada sino son seys u ocho, [...] y los mas darian lo que tienen porque les diesen licencia para salir de la tierra. Assi que las grandes necessidades que se han passado y passan muchos, y la miseria de la tierra, y el no aver otro modo para sustentarse, y el no poder salir de la tierra, y el estar impossibilitados a la restitucion con el conoscimiento de su miseria y desseo de redemirla, los ha hecho habiles para ser absueltos", Rada, "Carta a fray Alonso de la Vera Cruz, Calompit, 16 de julio de 1577”, BNF, Fonds Espagnol, M F 13184, 325.8, fols. 37-38. 
Finally, the colonial administration decided that the restitution that was claimed could be considered as compensated for by the costs and services of protecting the Natives and this was the end of the matter.

Tributes also proved to be a delicate matter, just as they had been in Mexico. Rada's position followed a similar line to the one he had pursued on the issue of Confession. His first instinct was to protest against the abuses which were committed by the secular authorities in charging the Natives three maes per person when the vast majority could barely afford one. ${ }^{111}$

The tribute exacted from them now, three gold maes per Indian, seems so excessive to we who have lived and dealt with them from the outset, and who know their work and the tools they have to work the land, and [who know] that they only sustain themselves with great difficulty and that they even live on roots for part of the year, and that the common people barely have a blanket with which to cover themselves [...], and so in general, anything that is taken from the Indians above the value of one maes in food and clothing is cruelty. ${ }^{12}$

Rada also denounced the systematic fraud in the collection of tributes: "And even the things that they used to earn their living by are interfered with, [...] they say that they take things for far less than they are usually valued at among themselves".113 This same complaint also appeared in another of Rada's letters to Vera Cruz, "And a blanket that is worth four maes among the Indians

111 "A maes of gold is commonly worth two reals and when gold is worth more, the maes is worth two reals and a half", Calkins Forster, The Encomienda System in the Philippine Islands: 1571-1597, 23. The interim governor, Guido de Lavezaris, thought that tribute of three maes was completely insufficient to pay the expenses of the religious instruction of the natives and the protection of the land. This opinion criticised the contrary position of Rada. Lavezaris, "Respuesta al parescer del P. Fray Martín de Rada, provincial de los Agustinos, Manila, 17 de julio de 1574", AGI, Patronato, 24, R. 29.

112 "El tributo que se les lleba agora ques tres maez de oro a cada yndio, es tan excesibo, a lo que nos paresçe, a los que desde el principio bivimos e tratamos con ellos y sabemos su trabajo dellos y los ynstrumentos con que labran la tierra y que con gran dificultad se sustentan y aun parte del año se sustentan con rrayzes y que la gente comun apenas alcança una manta con que se bestir [...] que todo lo que se llebare a cada yndio en general arriba de valor de un maez en comida e ropa ques crueldad", "Parescer del provincial fray martin de rrada agustino sobre las cosas destas yslas, Manila, 21 de junio de 1574", AGI, Patronato 24, R. 29.

113 "Y aun las cosas en que solian ellos tratar y grangear su vida son estorvados, [...] dizen que las toman mucho mas baratas de lo que suele valer entre ellos", "Parescer del provincial fray martin de rrada agustino sobre las cosas destas yslas, Manila, 21 de junio de 1574", AG I, Patronato 24, R. 29. 
themselves is taken for two when it is going towards the tribute". 114 It was an abuse that was already common in Mexico, as seen in the counsels given by Vera Cruz to the Marquis of Falces, appointed Viceroy of Mexico in 1566, "what has a value of 15 , they take for ten".115 Nonetheless, Rada was not in favour of ending tribute collections, given that,

The people of these islands are so miserable and keep their faith and word so little among themselves that they never trust or are certain until the tribute is paid, a little or a lot. [...] And, partly to be sure of them, at times it is necessary to ask them for something in advance. ${ }^{116}$

Vera Cruz was a key figure in 16th-century Mexico where he had a long-lasting cultural impact. He contributed more than anyone to the creation of libraries and the development of the embryonic university to a level comparable to the great educational institutions in Spain. Rada, as highly intelligent as he was well-prepared, tried to follow in his footsteps in almost everything, but he was a colonial official and under the orders of governors, some of whom he detested, who used him for his technical abilities rather than his worth. His name has survived thanks to the very fine account he wrote of his journey to China, but his impact on the remote colony was meagre and fleeting.

The School of Salamanca influenced the administration of the New World insofar as many of its former students were placed in positions of responsibility there, both civil and ecclesiastical. Its presence in America and the Philippines introduced a humanist and rational element into the cruel disorder of the conquests and provided a consistent cultural core for the New World its alumni arrived in. From their positions, they denounced the abuses of the conquest and, drawing essentially on Vitoria and Soto, raised their voices in calling for

\footnotetext{
114 "Y en las mantas, la que vale quatro maes entre los mismos indios, se toma en nombre de dos en el tributo", Rada, "Carta a fray Alonso de la Vera Cruz, Calompit, 16 de julio de 1577", BNF, Fonds Espagnol, M F 13184, 325.8, fols. 37-38.

115 "Y lo que vale 15, toman ellos por diez", "Los avisos que se dieron al señor marqués de Falces quando yva a Nueva España, 1566”, in Burrus, Vera Cruz's writings, Vol. v, 37.

116 "Es gente tan miserable estos destas islas, y guardan entre si tan poca fidelidad y palabra, que jamas fian ni se aseguran hasta aver pagado tributo, poco o mucho. [...] Y en parte para assegurarlos es menester a las vezes pedirles algo de antemano", Rada, "Carta a fray Alonso de la Vera Cruz, Calompit, 16 de julio de 1577", BNF, Fonds Espagnol, M F 13184, 325.8 , fols. $37-38$.
} 
the conquests to be better managed but not for them to be brought to a halt. The same happened with the encomiendas and abusive tributes which did not cease to exist and which they all finally accepted as inevitable in order to perpetuate Spanish dominion in America.

This same situation was repeated in other regions of the empire. To give just one example, José de Acosta, a learned Jesuit and alumnus of Alcalá, where he imbibed the teachings of Vitoria, arrived at the same conclusion in Peru. Citing Vitoria, Soto, and Covarrubias abundantly, he concluded that it was necessary for Spain to remain in America because of the risks to the Natives themselves if they were abandoned, a principle which Acosta also used to excuse the problem of the restitution of the goods requisitioned by the conquistadores. ${ }^{117}$

Finally, the thought of the School of Salamanca as represented by Vitoria, Vera Cruz, and Acosta is intimately linked to the origins of European colonial expansion. Its intention, articulated with impeccable method, was to endow the desire for conquest, which was a reality that could not be ignored, with justifiable reasons and to mitigate the suffering of the Natives as much as possible, especially as it proved to be as harmful to the colonised as it was to the colonisers.

\section{Bibliography}

\section{Manuscripts}

Consejo de Indias, "Memoria de las cosas que su Magestad debe enviar al Rey de Taybin [1580]", Archivo General de Indias, Sevilla (AGI), Patronato, 25, R. 3.

Herrera, Diego de, "Carta de fray Diego de Herrera a Felipe II, dando cuenta de su viaje a la Nueva España y regreso a la isla de Panay, de la destrucción en que está la tierra, con otras muchas noticias de interés, Isla de Panay, 25 de julio de 1570", AGI, Filipinas, 84, N. 1.

Herrera, Diego de and Martín de Rada, "Memoria de los Religiosos de las yslas del poniente de cosas quel padre Diego de herrera á de tratar con su magestad o su Real consejo de yndias, Manila [1572]", AG I, Filipinas, 84.

Lavezaris, Guido de, "Respuesta al parescer del P. Fray Martín de Rada, provincial de los Agustinos, Manila, 17 de julio de 1574", AGI, Patronato, 24, R. 29.

Rada, Martín de, "Carta del P. Martín de Rada al Virrey de México, dándole importantes noticias sobre Filipinas, Cebú, 8 de julio de 1569”, AGI, Filipinas, 79.

117 Pereña, La Escuela de Salamanca, 99-104. 
Rada, Martín de, "Carta de Martín de Rada al Virrey de Nueva España, dando cuenta de la gran miseria y destrucción a que ha venido aquella tierra por los daños y robos que se hacen a los naturales. Panay, 21 de julio de 1570", AG I, Patronato, 24, r. 9.

Rada, Martín de, "Copia de una carta quel Padre fray martin de rrada provincial de la orden de San Agustin que reside en la china escribe al virrey de la nueva españa fecha en la ciudad de manilla a 10 de agosto de 1572", AGI, Patronato, 24, n. 1, R. 22.

Rada, Martín de, "Carta de Fray Martin de Rada al Virrey de la nueva España, hecha en la ciudad de Manila de las yslas del poniente en primero de junio de 1573", AGI, Patronato, 24, R. 22.

Rada, Martín de, "Parescer del provincial fray martin de rrada agustino sobre las cosas destas yslas, Manila 21 de junio de 1574", AG I, Patronato 24, R. 29.

Rada, Martín de, "Carta al Virrey de México del P. Martín de Rada, dándole cuenta de cómo Juan de Salcedo fué a la conquista de Vicor e Ilocos, atropellos que se cometen con los indios, aumento de la doctrina, de las viruelas, y clases de esclavitud. Manila, 30 de junio de 1574", AG I, Filipinas, 84.

Rada, Martín de, "Aviso de fray martín de rada sobre las confessiones de los encomenderos. Manila, 1575”, Archivo de la Orden de Predicadores, Universidad de Santo Tomás (AOpUST), T. viI, fol. 388.

Rada, Martín de, "Relaçion Verdadera delas cosas del Reyno de Taibin por otro nombre china y del viaje que a el hizo el muy Reverendo padre fray martin de Rada provinçial que fue dela orden del glorioso Doctor dela yglesia San Agustin, que lo vio y anduvo en la provinçia de Hocquien año de 1575 hecha por el mesmo", Bibliothèque Nationale de France, Paris (BNF), Fonds Espagnol, 325.9 M F 13184, fols. 15-30.

Rada, Martín de, "Carta de Martín de Rada a Felipe II, Manila, 1 de mayo de 1576”, AGI, Filipinas 84 .

Rada, Martín de, "Carta de Martín de Rada al virrey de México, Manila, 4 de mayo de 1576", AGI, Filipinas, 84 .

Rada, Martín de, "Al muy reverendo padre nuestro el maestro fray Alonso de la Vera Cruz provincial de los agustinos en la nueva España, mi padre. Manila, 3 de junio de 1576", BNF, Fonds Espagnol, 325·7, M F 13184, fols. 35-36.

Rada, Martín de, “Carta de Fray Joan de Alva, Fray Martín de Rada, Fray Francisco de Ortega, Fray Agustín de Alburquerque a Fray Alonso de Vera Cruz, Manila, 8 de junio de 1577", BNF, Fonds Espagnol, 325.7, M F 13184, fols. 79-80.

Rada, Martín de, "Carta del Provincial, Definidores y Prior del convento de San Agustín de Manila al Virrey de Nueva España, sobre el estado de aquellas islas y lo mal que gobierna el Doctor Don Francisco de Sande, Manila, 8 de junio de 1577", AGI, Filipinas, 84 .

Rada, Martín de, "Al muy reverendo padre nuestro el maestro fray Alonso de la Vera Cruz, provincial de los agustinos en la nueva españa, Calompit, 15 de julio de 1577", BNF, Fonds Espagnol, 325.8, M F 13184, fols. 37-38. 
Rada, Martín de, "Al muy reverendo padre fray Juan Cruzat en Xanacatepeque de la orden de nuestro señor San Agustin en nueva españa a 15 de julio, Calompit, 15 de julio de 1577", BNF, Fonds Espagnol, 325.5, M F 13184, fols. 31-32.

Rada, Martín de, "Al muy reverendo padre nuestro padre Alonso de la Vera Cruz provincial de los agustinos en Nueva España donde es su tierra, De calonpit a 16 de julio de 1577", BNF, Fonds Espagnol, 325.9, M F 13184, fols. 39-46.

Rada, Martín de, "Al muy reverendo padre nuestro, fray Alonso de la Vera Cruz, provincial de la orden de nuestro padre San Agustin. Nuestro padre en la Nueva España, Burney, 25 de abril de 1578”, BNF, Fonds Espagnol, 325.6, M F 13184, fols. 33-34.

Ricci, Matteo, Michele Ruggieri and Alessandro Valignano, "Memorandum de las cosas que han de venir para el presente que Su Santidad ha de embiar al Rey de la China [1588]", Archivum Romanum Societatis Iesu, Roma (ARSI), Fondo Jesuitico, 722/2.

Ronquillo, Gonzalo de, "Memoria de las cosas que se careçe en la China y serán muy estimadas en ella", AG I, Indiferente, 1956, L. 2, fol. 114.

\section{Printed Sources}

Basalenque, Diego de, Historia de la provincia de San Nicolás Tolentino de Michoacán, México 1673: Imprenta de la viuda de Bernardo Calderón.

Castro, Agustín María de, Osario venerable, Manila 178o: [s.n.], ed. Merino, Manuel, Misioneros augustinos en el Extremo Oriente, 1565-1780 (Osario venerable, 1780), Madrid 1954.

Encinas, Diego de, Provisiones, Cedulas, Capitulos de ordenanças, instrucciones, y cartas, libradas y despachadas en diferentes tiempos por sus Magestades de los señores Reyes Catolicos don Fernando y doña Ysabel, y Emperador don Carlos gloriosa memoria, y doña Iuana su madre, y Catolico Rey don Felipe, con acuerdo de los señores Presidentes, y de su Consejo Real de las Indias, que en sus tiempos ha avido tocantes al buen govierno de las Indias, y administracion de la justicia en ellas, Madrid 1596: Imprenta Real.

Felipe II, "Ordenanzas de descubrimiento, nueva población y pacificación de las Indias, Bosque de Segovia, 13 de julio de 1573", in Morales Padrón, Francisco (ed.), Teoría y leyes de la conquista, Madrid 1979, 489-518.

Grijalva, Juan de, Crónica de la orden de N.P.S. Agustin en las provincias de la Nueva España. En quatro edades desde el año 1553 hasta el de 1592, México 1624: Joan Ruiz.

Loarca, Miguel de, Tratado de las Yslas Philippinas, Colección Muñoz, A/107, Ms 9/ 4842, fols. 267r-299r, in Blair, Emma and James Robertson (eds.), The Philippine Islands, 1493-1803, Vol. v 1582-83, 55 vols., Cleveland 1903, 34-187.

Pantoja, Diego de, "Carta del padre Diego de Pantoja, religioso de la Compañía de Jesús, para el padre Luis de Guzmán, provincial de la provincia de Toledo", in Moncó, Beatriz (ed.), Relación de la entrada de algunos padres de la Compañía de Jesús en China y particulares sucesos que tuvieron y de cosas muy notables que vieron en el mismo Reino, Madrid 2011. 
San Agustín, Gaspar de, Conquistas de las islas Philipinas: la temporal por las armas del Señor Don Phelipe Segundo El Prudente; y la espiritual, por los religiosos del Orden de San Agustín, Madrid 1698: Manuel Ruiz de Murga.

Soto, Domingo de, De iustitia et iure libri decem, Salamanca 1553: Andrea de Portonaris. Vela, Santiago, Ensayo de una biblioteca Ibero-Americana de la Orden de San Agustín, 7 vols., Madrid 1913-1925: Monasterio de El Escorial.

Vera Cruz, Alonso de, The Writings of Alonso de la Vera Cruz, 5 vols., ed. by Burrus, Ernest, St. Louis 1968-1978.

Vera Cruz, Alonso de la, Parecer razonado sobre el título de dominio del Rey de España sobre las personas y tierras de indios, in Burrus, Ernest (ed.), Vera Cruz's Writings, vol. I, St. Louis 1968, 77-87.

Vera Cruz, Alonso de la, Parecer que dieron los religiosos de la orden de Santo Agustín en la Nueva España, estando en ella el licenciado Tello de Sandoval, 1544, in Burrus, Ernest (ed.), Vera Cruz's Writings, vol. v, St. Louis 1978, 103-113.

Vera Cruz, Alonso de la, Recognitio summularum, México 1554: Juan Pablo Bricense.

Vera Cruz, Alonso de la, Dialectica resolutio cum textu Aristotelis, México 1554: Juan Pablo Bricense.

Vera Cruz, Alonso de la, Speculum coniugiorum, México 1556: Juan Pablo Bricense.

Vera Cruz, Alonso de la, Physica speculatio, México 1557: Juan Pablo Bricense.

Vera Cruz, Alonso de la, Appendix ad Speculum congiugiorum [...]. Iuxta diffinita in sacro universali Concilio Tridentino, circa matrimonia clandestina, Alcalá 1571: Pedro Cosin.

Vera Cruz, Alonso de la, Speculum coniugiorum. Espejo de matrimonios, ed. Barp Fontana, Luciano, 3 vols., México 2009-2013.

Vera Cruz, Alonso de la, Relectio de decimis, 1554-1555. Tratado acerca de los diezmos, ed. Barp Fontana, Luciano, México 2015.

Vitoria, Francisco de, Relectio De indis, ed. Hernández Martín, Ramón, in Vitoria, Francisco de, Relecciones jurídicas y teológicas, ed. Osuna Fernández-Largo, Antonio, Salamanca 2017 .

\section{Literature}

Álvarez, Luis, "Fray Tomás de Villanueva, mentor espiritual y promotor de las misiones agustinas en América” in Rodríguez, Isacio (ed.), Agustinos en América y Filipinas, vol. I, 2 vols., Valladolid / Madrid 199o, 61-94.

Anghie, Anthony, Imperialism, Sovereignty and the Making of International Law, Cambridge 2005 .

Barrañón, Armando, "Copérnico en la Física de Fray Alonso de la Veracruz", in Razón y Palabra 40 (2004), 1-8.

Bernal, Antonio-Miguel, "La Carrera del Pacífico: Filipinas en el sistema colonial de la Carrera de Indias", in Cabrero, Leoncio (ed.), España y el Pacífico. Legazpi, Madrid 2004, vol. I, 485-526. 
Blair, Emma and James Robertson (eds.), The Philippine islands, 1493-1898, as related in contemporaneous books and manuscripts, 55 vols., Cleveland 1903-07.

Cabrero, Leoncio (ed.), España y el Pacífico. Legazpi. Tomo I, Madrid 2004.

Calkins Forster, Jane, The Encomienda System in the Philippine Islands: 1571-1597 (MA Thesis), Chicago 1956.

Cerezo de Diego, Prometeo, Alonso de Veracruz y el derecho de gentes, México 1985.

Esteban Piñeiro, Mariano, "Las academias técnicas en la España del siglo XVI", in Quaderns d'història de l'enginyeria 5 (2002-03), 10-19.

Folch, Dolors, "Sinological Materials in Some Spanish Libraries", in Wilson, Ming and John Cayley (eds.), Europe Studies China; Papers from an International Conference on the History of European Sinology (1992: Taipei, Taiwan), London 1995, 149-16o.

Folch, Dolors, "Biografia de fray Martín de Rada", in Huarte de San Juan. Geografía e Historia 15 (2008), 33-63.

Folch, Dolors, “Los libros de Martín de Rada", in Sinología Hispánica 6:1 (2018), 1-26.

Folger, Robert, Writing as Poaching: Interpellation and Self-fashioning in Colonial Relaciones de méritos y servicios, Leiden / Boston 2011.

Galende, Pedro (o.s.A.), Martín de Rada O.S.A. 1533-1578. Abad frustrado, misionero y embajador real, Manila 1980.

Goodrich, Luther and Chaoying Fang (eds.), Dictionary of Ming Biography, New York 1976.

Grice-Hutchinson, Marjorie, La Escuela de Salamanca: una interpretación de la teoría monetaria española, 1544-1605, Salamanca 2005.

Gutiérrez Escudero, Antonio, América:Descubrimiento de un mundo nuevo, Madrid 199o. Hanke, Lewis and Agustín Millares Carlo (eds.), Cuerpo de documentos inéditos del siglo XVI sobre los derechos de España en las Indias y las Filipinas, México 1943.

Hanke, Lewis, "La libertad de palabra en Hispanoamérica en el siglo XVI", in Cuadernos americanos 26 (1946), 185-201.

Hanke, Lewis, The Spanish Struggle for Justice in the Conquest of America, Philadelphia 1949 .

Headley, John, “Spain's Asian Presence, 1565-159o: Structures and Aspirations", in Hispanic American Historical Review 75:4 (1995), 623-646.

Lazcano, Rafael, Fray Alonso de Veracruz (1507-1584). Misionero del saber y protector de indios, Madrid 2007.

Loon, Piet Van der, The Manila Incunabula and Early Hokkien Studies, 2 vols., London 1966-67.

Martín de la Hoz,JoséCarlos, “Las relecciones teológicas de Domingo de Soto:cronología y ediciones", in Scripta Theologica 16 (1984), 433-441.

Mojarro, Jorge, "La defensa del indio en la temprana literatura hispano-filipina colonial", in Revista de Crítica Literaria Latinoamericana 88 (2018), 13-31. 
Navarro, Bernabé, "La Physica Speculatio de fray Alonso de la Veracruz y la filosofía de la naturaleza o Cosmovisión aristotélica del Nuevo Mundo" in Beuchot, Mauricio and Bernabé Navarro (eds.), Dos homenajes: Alonso de Veracruz y Francisco Xavier Clavijero, México 1992, 13-24.

Palomero Páramo, Jesús Miguel, "El convento agustino en Nueva España: concepto de grandeza”, in Rodríguez, Isacio (ed.), Agustinos en América y Filipinas, vol. II, 2 vols., Valladolid / Madrid 199o, 577-617.

Pereña, Luciano, La Escuela de Salamanca. Proceso a la conquista de América, Salamanca 1986.

Rano, Balbino, "Métodos misionales de los agustinos en México" in Rodríguez, Isacio (ed.), Agustinos en América y Filipinas, vol. I, 2 vols., Valladolid-Madrid 199o, 95-115.

Rodríguez, Isacio, Historia de la Provincia agustiniana del Santísimo Nombre de Jesús de Filipinas, vols. XIII-XIV, 21 vols., Manila 1978.

Rodríguez, Isacio (ed.), Agustinos en Américay Filipinas, 2 vols., Valladolid / Madrid 1990.

Rubial García, Antonio, "Fray Alonso de la Veracruz, agustino. Individualidad y corporativismo en la Nueva España del siglo XVI", in Ponce Hernández, Carolina (ed.), Innovación y tradición en Fray Alonso de la Veracruz, México 2007.

Wang Romero, Alejandro, "Las listas de la compra. ¿Qué le regalamos a un emperador chino? El presente diplomático en la corte de Felipe II", in Temas Americanistas 40 (2018), 140-16o. 